\title{
Neutrophils in innate host defense against Staphylococcus aureus infections
}

\author{
Kevin M. Rigby • Frank R. DeLeo
}

Received: 23 September 2011 / Accepted: 14 October 2011 /Published online: 12 November 2011

(C) The Author(s) 2011. This article is published with open access at Springerlink.com

\begin{abstract}
Staphylococcus aureus has been an important human pathogen throughout history and is currently a leading cause of bacterial infections worldwide. S. aureus has the unique ability to cause a continuum of diseases, ranging from minor skin infections to fatal necrotizing pneumonia. Moreover, the emergence of highly virulent, drug-resistant strains such as methicillin-resistant $S$. aureus in both healthcare and community settings is a major therapeutic concern. Neutrophils are the most prominent cellular component of the innate immune system and provide an essential primary defense against bacterial pathogens such as $S$. aureus. Neutrophils are rapidly recruited to sites of infection where they bind and ingest invading $S$. aureus, and this process triggers potent oxidative and non-oxidative antimicrobial killing mechanisms that serve to limit pathogen survival and dissemination. S. aureus has evolved numerous mechanisms to evade host defense strategies employed by neutrophils, including the ability to modulate normal neutrophil turnover, a process critical to the resolution of acute inflammation. Here we provide an overview of the role of neutrophils in host defense against bacterial pathogens and discuss strategies employed by $S$. aureus to circumvent neutrophil function.
\end{abstract}

This article is published as part of the Special Issue on Immunopathology of Saphylococcal Infections [34:3].

K. M. Rigby • F. R. DeLeo $(\bowtie)$

Laboratory of Human Pathogenesis, Rocky Mountain

Laboratories, National Institute of Allergy and Infectious

Diseases, National Institutes of Health,

903 South 4th Street,

Hamilton, MT 59840, USA

e-mail: fdeleo@niaid.nih.gov
Keywords Staphylococcus aureus · MRSA · Neutrophil . Immune evasion

\section{Introduction}

Staphylococcus aureus has been a serious threat to human health throughout history and was one of the first bacterial pathogens to be identified. It was the ability of $S$. aureus to cause disease that led to its first description in human pus over 130 years ago by Sir Alexander Ogston [1, 2]. Since then, $S$. aureus has proven itself well adapted for interaction with humans and is currently a leading cause of human bacterial disease worldwide [3]. For example, S. aureus has been reported as the leading cause of bacterial infections involving bloodstream, lower respiratory tract, and skin and soft tissue in many industrialized countries including the United States, Canada, Europe, Latin America, and the Western Pacific [3]. S. aureus is also the most abundant cause of hospital-associated infections in the United States [4-6]. Correspondingly, this large number of infections creates a significant financial burden, making detrimental impacts on public health systems around the world [6]. With approximately half a million people acquiring staphylococcal infections in the USA per year, the cost of $S$. aureus healthcare-associated infections was estimated to exceed 14 billion dollars in 2003 [7, 8]. Interestingly, this versatile pathogen is considered a human commensal microbe, as it asymptomatically colonizes the anterior nares of $\sim 30 \%$ of non-institutionalized individuals [9]. Yet given the opportunity, $S$. aureus has the unique ability to cause a wide range of infections and syndromes, including skin and soft tissue infections, food borne illness, toxic shock syndrome, bacteremia, sepsis, endocarditis, osteomyelitis, necrotizing fasciitis, and pneumonia. An armament of 
well-studied virulence factors, ranging from secreted toxins to immune evasion molecules, lends $S$. aureus effective at causing disease [10]. In addition, the rise in occurrence and severity of infections over the last 70 years has been attributed to the evolution of highly virulent, drug-resistant strains that now challenge our ability to treat such infections. Further, there has been a recent increase in the burden of antibiotic-resistant $S$. aureus within the community setting $[11,12]$. These community-associated methicillin-resistant $S$. aureus (CA-MRSA) strains have an enhanced virulence potential, in that they are able to cause a wide range of disease in otherwise healthy individuals, drastically changing previous clinical epidemiology of methicillin-resistant S. aureus (MRSA) [13]. The enhanced virulence potential is related in part to the ability of these strains to circumvent killing by human polymorphonuclear leukocytes (PMNs or neutrophils), the most prominent cellular host defense against invading microorganisms.

This article will provide a brief history of the rise of highly-virulent, drug-resistant $S$. aureus strains, an overview of the role of neutrophils in host defense, and review immune evasion strategies employed by $S$. aureus to circumvent neutrophil function, including strategies yielding the enhanced virulence of CA-MRSA strains.

\section{S. aureus and antibiotics: a brief history}

S. aureus is notoriously adept at acquiring resistance to antibiotics, owing to much of the pathogen's recent success $[11,14]$. Inasmuch as the development and widespread clinical use of penicillin in the early 1940s marked the beginning of the "antibiotic era," reports of $S$. aureus strains harboring resistance to penicillin by 1942 marked the beginning of our critical, ongoing battle against antibiotic resistance [15]. Thereafter, the prevalence of penicillinresistant $S$. aureus (PRSA) increased dramatically in nosocomial settings, with the increase being attributed completely to the use of penicillin [16-18]. Increases in the number of PRSA infections lead to the inefficacy of penicillin treatment within 10 years of the miracle drug's introduction, necessitating the development of alternative treatments [17, 19]. Likewise, the introduction of methicillin - a $\beta$-lactam antibiotic developed for treatment of PRSA infections - in 1959 quickly led to the onset of a second "epidemic wave" of antibiotic resistance, as infections caused by methicillinresistant strains were reported 2 years later in 1961 [17, 20, 21]. Thereafter, MRSA became endemic to hospitals and health care facilities worldwide, leading to the global MRSA pandemic in health care settings that continues today [3, 17, 22]. A high percentage of hospital-associated $S$. aureus infections in the USA are caused by MRSA [7, 23, 24]. Notably, invasive MRSA infections are considered a major cause of human mortality in the USA - there were approximately 19,000 deaths in the USA in 2005 and the mortality rate for invasive MRSA infections was reported as $20 \%$ [5]. In the USA, MRSA is likely the leading cause of death by any single infectious agent, with fatalities from MRSA infection estimated to surpass those caused by HIV/AIDS [5, 25]. Antibiotic use within the nosocomial setting has created high selective pressure for development of antibiotic resistance, and $S$. aureus has acquired resistance to virtually all antibiotics [14, 26]. Multidrug-resistant MRSA strains, which combine resistance to $\beta$-lactam antibiotics with resistance to other classes of antibiotics, are becoming increasingly frequent in the healthcare setting, representing a major concern for treatment of MRSA infections [11]. Taken together, the high occurrence of infections caused by drug-resistant $S$. aureus is problematic and demonstrates the urgent need for development of novel treatment strategies.

\section{Rise of community-associated MRSA}

The majority of infections caused by MRSA have historically been hospital-associated, occurring in immunocompromised individuals or in patients with pre-disposing risk factors, such as surgery, surgical incisions, the presence of indwelling medical devices, or pre-existing infections [6, 27-29]. However, MRSA epidemiology changed in the 1990s with reports of infections caused by strains of MRSA occurring outside of the healthcare setting in otherwise healthy individuals, the first reports of bona fide CAMRSA infections [12, 29]. CA-MRSA also spread rapidly among diverse groups of healthy individuals, demonstrating an enhanced transmissibility and/or ability to colonize, in addition to being highly virulent $[11,18,30-41]$. CAMRSA infections have been reported in regions all over the world, including Asia, Australia, Canada, Europe, South America, and the USA, rapidly reaching pandemic proportions [42-51]. The epidemic spread of CA-MRSA in the USA has led to an overall increase in the burden of MRSA [52]. Concomitant increases in staphylococcal burden have been observed worldwide since the emergence of CAMRSA [51, 53-55]. The majority of infections caused by CA-MRSA present as skin and soft tissue infections $(\sim 90 \%)$ and most are abscesses or cellulitis with purulent drainage [52, 53, 55-57]. However, the most prominent CA-MRSA strains also have a proven ability to cause severe invasive diseases such as necrotizing fasciitis and necrotizing pneumonia, rarely seen before the rise of CAMRSA [17, 29, 58-63]. Although invasive infections associated with CA-MRSA are relatively infrequent, they accounted for $14 \%$ of all invasive MRSA-associated fatalities in the USA in 2005 [5]. Predominant CA-MRSA 
strains such as pulsed-field gel electrophoresis (PFGE) types USA300 and USA400 are genetically distinct from traditional HA-MRSA strains in part because they contain a unique staphylococcal cassette chromosome (SCC) mec element (SCCmec type IV) [17, 64-68]. In contrast to larger SCCmec elements that encode resistance to multiple antibiotics, SCCmec type IV provides resistance to solely $\beta$-lactam antibiotics with apparently little or no fitness cost to the pathogen, likely contributing to the success of CAMRSA strains [17, 64-68]. Other genetic and molecular factors are associated with the unique ability of CA-MRSA strains to disseminate rapidly and cause disease in otherwise healthy individuals. These factors will be discussed in further detail below.

The ability of $S$. aureus to cause disease has fueled much research effort aimed at understanding the intricacies of interaction between $S$. aureus and host immune cells. This has resulted in the description of multiple, redundant strategies employed by $S$. aureus to evade and/or combat host immune response mechanisms. Many of these strategies serve to protect/defend the microbe against primary interaction with the innate immune response, which includes interaction with neutrophils. As the major cellular component of the innate immune system, neutrophils serve as the critical, primary defense against invading organisms, providing a rapid, non-specific, and potent response to infectious challenge. Defects in neutrophil function result in serious immune deficiencies and syndromes and are associated with recurrent and often fatal $S$. aureus disease $[69,70]$. Thus, there is no question that neutrophils are critical for defense against $S$. aureus infections. On the other hand, $S$. aureus - especially CA-MRSA - have the demonstrated ability to circumvent killing by human neutrophils, and can ultimately cause rapid destruction of these important host cells [71, 72]. This unique ability is linked to the enhanced virulence of these strains and their capacity to cause disease [13]. Understanding the complex interaction between $S$. aureus and human neutrophils is critical to understanding the ability of $S$. aureus to cause disease.

\section{Neutrophils in the innate immune response}

\section{A brief historical perspective}

Neutrophils are classically underappreciated professional phagocytes, with regard to the history and development of modern immunology. The focus of early immunologists was aimed at understanding the life-cycles and functions of lymphocyte sub-types, and their ability to play diverse roles in antigen presentation, direction and regulation of immune response, and cytotoxic capacity, all in the context of the novel concept of adaptive (acquired) immunity. Although non-specific innate immunity was appreciated, the only professional phagocytes of noted significance were mononuclear phagocytes - monocytes and macrophages. Unlike neutrophils, monocytes were known to be long-lived cells with significant metabolic capacity and the ability to produce immune regulatory factors. Moreover, they were well considered for their antigen-presenting capacity as well as the ability to differentiate into tissue macrophages and other fixed tissue cell types. The ability of neutrophils to rapidly migrate to sites of inflammation as well as their capacity to surround and engulf foreign bodies was described in the early twentieth century. However, subsequent studies demonstrating rapid neutrophil turnover in blood, short tissue life spans, small capacity for oxidative phosphorylation, utilization of primarily anaerobic metabolism, and little known capacity to synthesize new proteins, engendered neutrophils largely as end-stage cells with limited metabolic capacity [73-76].

However, research performed in the late 1960s marked the first of a large body of evidence that turned the tide for the underappreciated neutrophil. This work ultimately evolved into our modern understanding of innate immunity, which now encompasses the critical, diverse roles of neutrophils as potent executioners in host defense, and serve as an important interface between innate and adaptive immune responses. These early studies demonstrated for the first time that human neutrophils produce potent reactive oxygen species and contain antimicrobial proteins and enzymes in cytosolic organelles known as azurophilic granules [77-80]. Biochemical studies that continued through the late 1980s and early 1990s characterized in detail, additional, important capabilities of neutrophils including the assembly and activation of the phagocyte NADPH oxidase, mechanistic functions of granule proteins, the role of actin in the mobilization of phagocytic cells, and the discovery that bacterial-derived $\mathrm{N}$-formyl peptides induce chemotaxis and enhance microbicidal functions of neutrophils [81-90]. These studies quickly drew additional interest, sparking the use of neutrophils as model host cells for the study of new signal transduction pathways that included calcium transients, phosphorylation events, G protein-coupled receptors, and phospholipid signaling and metabolism [91-100]. Further validation of the diversity and importance of neutrophil function came with the more recent description of mechanisms underlying normal neutrophil turnover, which we now know occurs by spontaneous or constitutive apoptosis. The final stage of neutrophil differentiation can be considered as the induction of apoptosis, and this process leads to the recognition and phagocytosis of apoptotic neutrophils by macrophages [101-104]. In addition, apoptosis or a form of programmed cell death similar to apoptosis is typically induced by 
phagocytosis and subsequent activation of the cell. Timely removal of spent neutrophils serves to prevent inadvertent release of tissue-damaging molecules from dying neutrophils should they undergo lysis, and thereby promotes resolution of inflammatory response. [105]. Contrary to the classic institution, recent studies have clearly demonstrated a relatively high transcriptional capacity for neutrophils, with the potential to synthesize many new proteins in response to various stimuli $[106,107]$. This includes the production of multiple cytokines and chemokines, expanding the diverse function of neutrophils as regulators of immune function [108]. In corroboration, the importance of neutrophils was gradually placed in proper perspective with the description of several serious human diseases caused by underlying neutropenia and/or defects in neutrophil function. These conditions are associated with an increased risk of infection from bacteria and fungi [70]. Additionally, medically induced neutropenia, e.g., during cancer chemotherapy or use of cytotoxic drugs, is the most common immunodeficiency associated with significant morbidity, demonstrating in part the relationship between functions served by neutrophils and the outcome of infection [109112]. Collectively, the current body of evidence disputes the early, naïve concept of the neutrophil, unequivocally demonstrating the indispensable nature and diverse function of these cells in the defense against many invading microorganisms. Ultimately this has redefined the function and importance of the innate immune system.

\section{Neutrophil development}

Neutrophils are short-lived granulocytes derived from pluripotent hematopoietic stem cells in the bone marrow [113]. Although granulocytes and lymphocytes are derived from similar pluripotent stem cells, granulopoiesis is distinct from that of lymphopoiesis, requiring a unique set of transcriptional regulators that facilitate the maturation of granule proteins and surface markers/receptors characteristic of granulocytes [114, 115]. Further distinction of granulocytes includes morphological characteristics, such as the presence of a multi-lobed nucleus. The majority of hematopoiesis is devoted to granulopoiesis, as nearly $60 \%$ of leukocytes within the bone marrow are granulocyte precursors $[73,75]$. Early in the neutrophil differentiation process, cells develop phagocytic capacity followed by development of oxygen-dependent microbicidal activity, increased adhesiveness, cell motility, chemotactic response, and other cell type-specific traits, proceeding through a well-characterized, carefully regulated, multi-step progression into mature neutrophils [113, 114, 116]. During maturation the number of mitochondria and ribosomes decreases, while glycogen granules, the main source of energy, fill the cytoplasm of mature neutrophils [70, 73].
There are two major populations of granules present in mature neutrophils. Primary or azurophilic granules, which are first to develop during granulopoiesis, contain myeloperoxidase (MPO) and a variety of proteolytic enzymes (cathepsins, proteinase-3, and elastase), antimicrobial defensins, and bactericidal/permeability-increasing protein [73, 117-121]. These microbicidal granules are considered unique from lysosomes, in that they lack traditional lysosomal membrane markers and traffic as regulated secretory granules [122-125]. The other major type of granules present are secondary or specific granules, which mature late during differentiation, and contain a number of functionally important membrane proteins including flavocytochrome $b_{558}$, lactoferrin, collagenase, as well as receptors for chemotactic peptides, cytokines, opsonins, adhesion proteins, and extracellular matrix proteins [73, 117, 126-136]. Upon maturation, neutrophils are released into the bloodstream where they circulate for $\sim 10-24 \mathrm{~h}$ before migrating into tissue where they may function for an additional 1-2 days before undergoing apoptosis and being cleared by macrophages [73-75, 103, 104, 137, 138]. Normal neutrophil turnover in an average adult is on the order of $10^{11}$ cells per day [75]. In addition to maintaining steady-state levels of circulating neutrophils, the hematopoietic system has the remarkable ability to drive "emergency" granulopoiesis in response to the increased demand of infection, expanding the pool of neutrophils in circulation when necessary $[139,140]$.

Neutrophil recruitment

A dynamic portion of circulating neutrophils roll along the walls of postcapillary venules, via transient interactions with endothelial cells, surveying connective tissue, mucosal membranes, skeletal muscle, and lymphatic organs for signs of tissue damage, inflammation, or invading microorganisms [141-143] (Fig. 1). This dynamic pool of marginating cells searches for the presence of host- and/or pathogen-derived chemotactic signals or chemoattractants. In response to damage or the presence of invading pathogens, a variety of host cells such as monocytes, macrophages, mast cells, fibroblasts, keratinocytes, endothelial and epithelial cells produce and secrete potent inflammatory mediators and neutrophil chemoattractants. These mediators include interleukin8 (IL-8, CXCL8), GRO $\alpha$ (CXCL1), granulocyte chemotactic protein 2 (GCP2, CXCL6), and leukotriene $\mathrm{B}_{4}$ $\left(\mathrm{LTB}_{4}\right)$, which bind and engage specific surface receptors on surveying neutrophils. These signals direct neutrophil chemotactic movement out of intravascular circulation to sites of damage or infection within tissues, resulting in a rapid influx and accumulation of neutrophils. S. aureus surface components such as lipoteichoic acid (LTA) or 


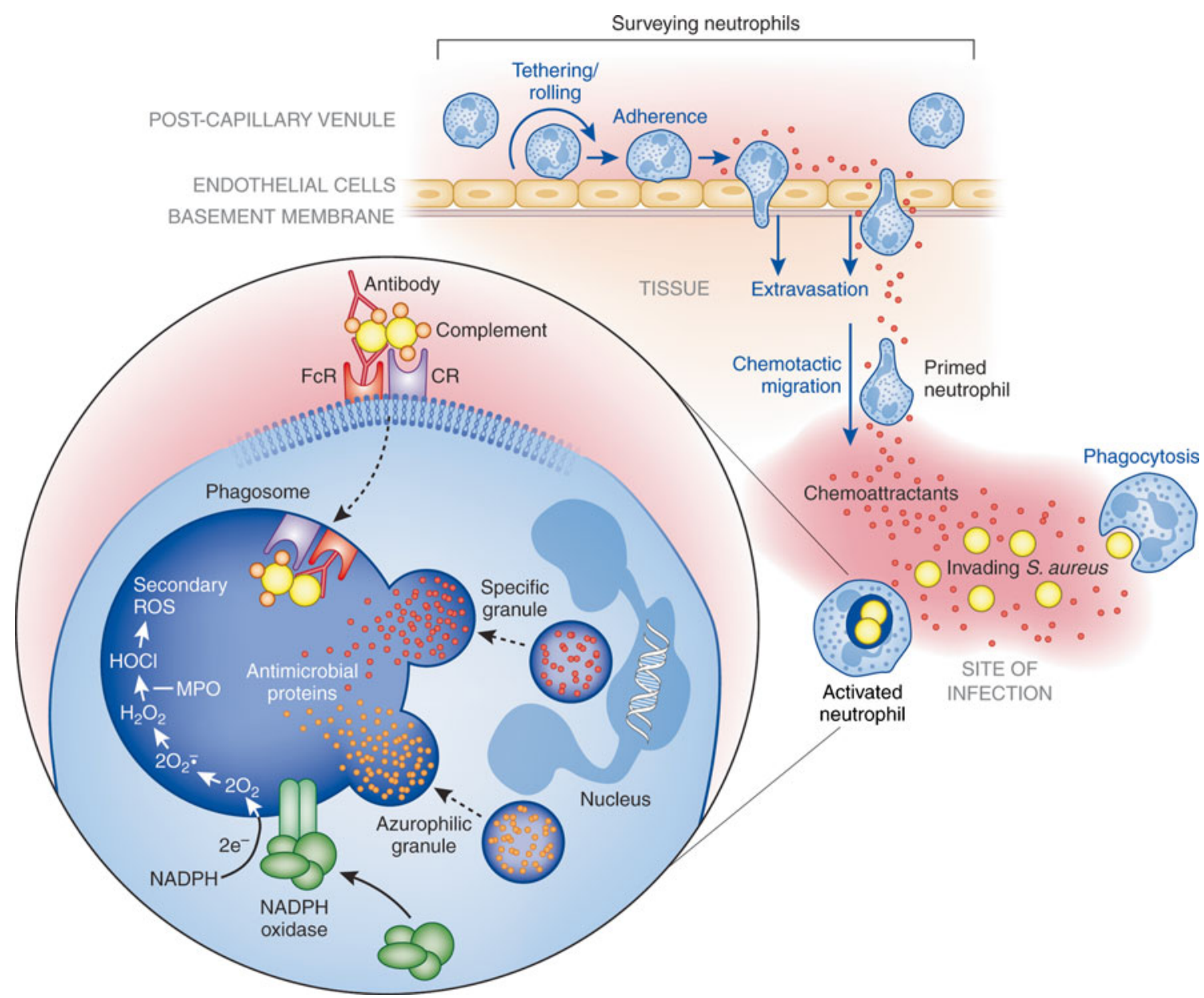

Fig. 1 Neutrophil emigration from vascular space to site of infection followed by phagocytosis and microbial killing. Marginating neutrophils survey post-capillary venules for signs of inflammation or invading microorganisms, undergoing transient tethering interactions with endothelial cells that facilitate neutrophil rolling along the endothelial wall and allow neutrophils to search for host- and/or microbe-derived chemotactic signals. Chemotactic molecules diffusing from the site of infection and into the bloodstream bind specific receptors on the neutrophil surface, arresting the rolling process and inducing firm adherence to the endothelial wall. Firm adherence

capsular polysaccharide as well as secreted molecules such as toxic shock syndrome toxin (TSST)-1, staphylococcal enterotoxin A, and staphylococcal enterotoxin B have been shown to elicit IL-8 production by monocytes, epithelial cells, and endothelial cells [144-147]. Additionally, CD4+ T-cells stimulated with $S$. aureus capsular polysaccharide produce cytokines that recruit neutrophils to sites of infection, demonstrating the range of cell types that play a role in the recruitment of neutrophils [148, 149]. $S$. aureus surface components, primarily peptidoglycan (PGN), have also been shown to activate the complement cascade, inducing production of the complement cascade component C5a, another potent neutrophil chemotactic molecule [150]. Bacterial-derived products such as $\mathrm{N}$-formyl peptides or the phenol-soluble modulins (PSMs) produced by $S$. aureus subsequently leads to neutrophil transmigration through the endothelial wall into the tissue, a process known as extravasation. Once in the tissue, primed neutrophils chemotactically migrate to the site of infection where they recognize and phagocytose invading microorganisms. Within the phagosome of the activated neutrophil, microbes are destroyed by NADPH oxidase-derived reactive oxygen species and antimicrobial proteins released upon granule fusion with the phagosome (degranulation). See text for details. $C R$ complement receptor, $F c R$ Fc receptor, $M P O$ myeloperoxidase

have the demonstrated ability to recruit neutrophils directly [150-152].

Many neutrophil chemotactic molecules also act as priming agents, serving to enhance neutrophil responses to a second stimulus. Neutrophil priming, first described in the early 1980 s, is classically defined as the ability of a primary agonist, typically at sub-stimulatory concentrations, to enhance the production of superoxide in response to a second stimulus [153]. Since then, many studies have expanded on the original definition, going on to demonstrate that the priming process occurs on almost all levels of neutrophil function, including the enhancement of adhesion, phagocytosis, cytokine secretion, leukotriene synthesis, degranulation, and oxidative and non-oxidative microbicidal activities [154]. It is thought that priming prepares neutrophils for maximal 
response to invading microorganisms, thereby promoting efficient clearance of such invaders. Corroborating evidence to date demonstrates that the more responsive state of the neutrophil is attributable to (a) partial assembly of the NADPH oxidase, (b) reorganization of the plasma membrane and redistribution of signaling molecules into lipid rafts, (c) modulation of intracellular signaling intermediates, (d) mobilization of secretory vesicles and enrichment of specific surface receptors (CD11b/CD18), (e) cytokine secretion, and (f) transcriptional regulation of several gene families [70]. Although priming leads to observable phenotypic differences, it remains distinct from neutrophil activation in that it triggers neither release of azurophilic granules nor production of superoxide [13, 153, 155]. Neutrophil priming is induced by many host-derived factors, including cytokines, chemokines, growth factors, lipid-derived signaling molecules, as well as by physical cell-cell contact and adhesion [154]. Many bacterial-derived factors also induce neutrophil priming [154]. Some bacterial-derived products, such as S. aureus LTA, are agonists for Toll-like receptors (TLRs), which play a critical role in pathogen-mediated neutrophil priming and pathogen recognition (discussed below).

Upon recognition of chemotactic signals and/or neutrophil priming, neutrophils exit peripheral circulation by transmigration across the endothelial wall, a process known as extravasation (Fig. 1). The process of extravasation begins by tethering of neutrophils to endothelial cells, transient interactions that facilitate rolling of surveying neutrophils along the endothelial wall. Tethering interactions are mediated by a family of C-type lectin glycoproteins known as selectins, which are upregulated on the surface of cytokine-activated endothelial cells (E- and Pselectin), activated platelets (P-selectin), and primed neutrophils (L-selectin, CD62) [141, 156]. Selectins expressed on the surface of endothelial cells and neutrophils interact with their respective carbohydrate ligands on the opposing cell surface, resulting in initial tethering and subsequent rolling of neutrophils along the endothelial wall [157]. Rolling is arrested by integrin-dependent interactions via leukocyte adhesion molecules such as CD11a/CD18 (LFA1) and CD11b/CD18 (Mac-1), resulting in firm neutrophil adhesion $[158,159]$. Transmigration, facilitated by several neutrophil surface molecules including CD31 (PECAM1), CD54 (ICAM1), CD44, and CD47, may then proceed between or through endothelial cells into tissues [160-164]. Following extravasation into tissues, polarized neutrophils proceed to the site of infection by chemotaxis.

\section{Pathogen recognition and phagocytosis}

Once at the site of infection, the real work for neutrophils begins, as they bind and ingest invading microorganisms by a process known as phagocytosis, a critical first step in removal of bacteria during infection. Neutrophils recognize numerous surface-bound and freely secreted bacterial products such as PGN, lipoproteins, LTA, lipopolysaccharide, CpG-containing DNA, and flagellin. Such conserved bacterial products are generally known as pathogenassociated molecular patterns (PAMPs) and are recognized directly by pattern recognition receptors (PRRs) expressed on the surface of the neutrophil. Engagement of such receptors activates signal transduction pathways that prolong cell survival, facilitate adhesion and phagocytosis, induce release of cytokines and chemokines, elicit degranulation, and promote reactive oxygen species (ROS) production and release, ultimately contributing to microbicidal activity [154]. The importance of PRRs in host defense is perhaps exemplified by the enhanced susceptibility of TLR2 deficient mice to infection by $S$. aureus compared with wild-type mice [165]. Although many chemoattractant molecules and TLR ligands have the ability to elicit degranulation and ROS production, neutrophil activation generally requires concentrations of ligand/ stimulus higher than that required for priming and chemotaxis. Thus, activation is likely delayed until neutrophils reach sites of infection where concentrations of stimulatory ligands are highest.

NOD-like receptors are PRRs located in the cell cytoplasm rather than the plasma membrane or membranes of granules. These proteins serve to detect intracellular microbial components and respond similarly to other PRRs by inducing downstream signaling cascades involved in mediating inflammatory response and neutrophil function [166]. For example, NOD2 senses muramyl dipeptide derived from $S$. aureus PGN and subsequently promotes transcription of NF- $\mathrm{KB}$ target genes in the nucleus [166]. The collectins are a family of secreted, soluble C-type lectins such as mannan-binding lectin (MBL). Collectins are yet another type of PRR and bind and recognize carbohydrate moieties on the surface of invading microorganisms. These molecules enhance recognition by surface receptors on neutrophils (opsonization via the lectin pathway of complement activation), activate other PRRs, facilitate efficient phagocytosis, and elicit release of cytokines and production of ROS [167-169]. Peptidoglycan recognition protein (PGRP) is a secreted host protein that binds PGN and Gram-positive bacteria $[170,171]$. An isoform known as PGRP-short is produced by neutrophils and contributes directly to bactericidal activity rather than directing downstream signaling responses [172].

Although many PRRs such as TLRs enhance binding and recognition of microbes, there is little evidence to date demonstrating that these receptors induce phagocytosis directly, suggesting that PRRs may act as co-receptors [173]. That said, there are exceptions to this idea. For 
example, dectin-1, a C-type lectin, binds $\beta$-glucan residues on fungi and promotes phagocytosis and subsequent neutrophil activation, ultimately killing ingested fungi [174]. Unlike the unique phagocytic uptake induced by dectin-1, phagocytosis of most microorganisms is promoted or at least markedly enhanced by opsonization with serum host factors, such as specific antibody, complement, and/or MBL (generally fungi) [175]. For this purpose, neutrophils express multiple antibody-Fc and serum complement receptors, including CD16 (Fc $\gamma \mathrm{III}$, low affinity $\mathrm{IgG}$ receptor) [176, 177], CD23 (FceRI, IgE receptor) [178], CD32 (Fc $\gamma$ RIIa, low affinity IgG receptor) [179], CD64 (Fc $\gamma \mathrm{RI}, \mathrm{IgG}$ receptor) [70], CD89 (Fc $\alpha \mathrm{R}, \mathrm{IgA}$ receptor) [180], CIqR [181], CD35 (CR1) [182, 183], CD11b/CD18 (CR3) [184, 185], and CD11c/CD18 (CR4) [186]. Activation of complement facilitates the deposition of complement components $\mathrm{C} 3 \mathrm{~b}, \mathrm{iC} 3 \mathrm{~b}$, and $\mathrm{Clq}$ on the surface of invading microorganisms [70], and serum complement is fixed readily on the surface of antibody-coated microbes. Taken together, the combined action of PRRs, and complement and antibody receptors maximizes recognition and phagocytosis of invading microorganisms (Fig. 1).

The process of phagocytosis itself occurs independent of clathrin, relying on regulation of actin polymerization early in uptake and during formation of the nascent phagosome [187]. The phagosome serves to restrict nutrient sources and provides the neutrophil an isolated compartment that may be made replete with an array of toxic, microbicidal agents. Phagosomal maturation is a stepwise process involving fusion of neutrophil secretory vesicles and granules with the phagosome, which serves to modify phagosomal membrane composition, and contents and environment of the lumen [187]. This process also enriches the phagosome with transmembrane components of the NADPH oxidase, which in turn serve as the nidus for assembly of the enzyme complex. Neutrophils have remarkable phagocytic capacity, and for example, are able to ingest more than nine yeast particles measuring $2 \times$ $3 \mu \mathrm{m}$, themselves having a diameter of only $\sim 10 \mu \mathrm{m}$ [188].

The process of neutrophil phagocytosis triggers synthesis of a number of immunomodulatory factors [102, 189191]. Production of these factors by neutrophils recruits additional neutrophils, modulates subsequent neutrophil responses, and coordinates early responses of other cells types such as monocytes, macrophages, dendritic cells, and lymphocytes, thereby providing an important link between innate and acquired immune responses. Additionally, phagocytosis has been shown to accelerate programmed cell death (apoptosis) of neutrophils, a process known as phagocytosis-induced cell death (PICD) [102]. The phenomenon of PICD is now considered a final stage of neutrophil differentiation for activated cells and appears critical to the resolution of the inflammatory response [101, 154]. This phenomenon will be discussed further below.

\section{Neutrophil microbicidal activity}

Neutrophils employ numerous oxygen-dependent and oxygen-independent strategies to concertedly destroy invading microbes. Phagocytosis is accompanied by the generation of microbicidal ROS (oxygen-dependent) and fusion of cytoplasmic granules with microbe-containing phagosomes (degranulation). Degranulation enriches the phagosome lumen with antimicrobial peptides and proteases (oxygen-independent process), which in combination with ROS create an environment non-conducive to survival of the ingested microbe(s) (Fig. 1).

In the most classical sense, neutrophil activation is intimately linked with the production of superoxide and other secondarily derived ROS, an oxygen-dependent process known as the oxidative or respiratory burst [192]. High levels of superoxide are generated upon full assembly of the multi-subunit NADPH-dependent oxidase in both the plasma- and phagosomal membranes. The active enzyme complex is comprised of an integral membrane component, flavocytochrome $b_{558}$ (a heterodimer of gp91phox and p22phox), that acts as the catalytic core of the complex and is the electron transferase, and p40phox, p47phox, p67phox, Rac2, and Rap1A, that act as cofactors for oxidase activity [70, 192, 154]. In unstimulated neutrophils, these components are segregated into membrane (flavocytochrome $b_{558}$ and Rap1A) and cytosolic (p40phox, p47phox, p67phox) compartments. Upon activation, cytosolic components translocate rapidly to plasma and/or phagosomal membranes [193-196]. The NADPH oxidase transfers electrons from cytosolic NADPH to molecular oxygen outside of the cell or within the phagosomal compartment, thereby producing superoxide. Although superoxide is thought to have limited direct microbicidal capacity, the molecule is used to generate secondarily derived ROS such as hypochlorous acid, hydroxyl radical, chloramines, and singlet oxygen, all effective microbicides [197-200]. The ability of neutrophils to produce large amounts of superoxide relies on continued function of the $\mathrm{NADPH}$ oxidase, a process that requires rapid charge compensation and $\mathrm{pH}$ regulation in the phagosomal compartment [201, 202]. Oxidase assembly and activity is modulated by post-translational modifications of subunits (phosphorylation of p47phox) [203], interaction of subunits with lipid signaling molecules (interaction of p40phox with phosphoinositides) [204-206], and protein-protein interactions (e.g., SH3 domains present in p47phox, p67phox, p22phox) [207, 208]. The production of ROS derived from the NADPH oxidase is critical to host defense against invading microorganisms, as exemplified by chronic granulomatous disease 
(CGD), a hereditary disease characterized by defects in NADPH oxidase [209]. Patients with such defects suffer from recurrent bacterial and fungal infections, including infections caused by S. aureus [209].

The intricacy of concerted microbicidal efforts made by the neutrophil is evident by the augmentation of the oxygen-dependent microbicidal activity by MPO, an abundant hemeprotein stored within azurophilic granules [200]. In the phagosome, MPO catalyzes a reaction with chloride and hydrogen peroxide to produce hypochlorous acid, a potent oxidizing agent and microbicide, as well as secondary products such as chloramines, hydroxyl radical, and singlet oxygen [200]. The overall microbicidal contribution of the MPO-halide system has been debated, as patients with hereditary MPO-deficiency generally lack any increased susceptibility to infection, suggesting that ROS generated by NADPH oxidase and microbicidal activity of granule proteins may be sufficient to compensate for a lack of the MPO-halide system under certain conditions [200, 210]. A redundancy in function of the NADPH oxidase and the MPO-halide system was proposed by Rosen and Klebanoff [211]. On the other hand, neutrophil cytoplasts, which retain a respiratory burst but lack MPO, are unable to kill ingested $S$. aureus unless they are coated with MPO [212]. Furthermore, pharmacologic inhibition of MPO leads to a decreased ability of neutrophils to kill bacteria [213]. Neutrophils from MPOdeficient patients do retain microbicidal activity against several bacterial pathogens, although at a lower level compared to neutrophils from normal donors, implying a sub-maximal response [214]. Together, augmentation of the NADPH oxidase by MPO facilitates a most efficient response against invading microorganisms, while any redundancy in function further demonstrates the importance of the innate immune response.

Often overlooked in the past, oxygen-independent killing mechanisms make a major contribution to the unique microbicidal capacity of neutrophils. Evidence of the importance of these mechanisms lies in the ability of neutrophils to kill certain organisms under anaerobic (oxygen limiting) conditions, wherein oxygen-dependent generation of ROS does not occur [70]. Oxygenindependent microbicidal agents include neutrophil antimicrobial peptides (AMPs) and antimicrobial proteins such as $\alpha$-defensins, cathelicidins, azurocidin, cathepsins, lactoferrin, lysozyme, proteinase-3, and elastase [70, 215]. These agents are delivered by the regulated mobilization and targeted fusion of cytoplasmic granules with either plasma membrane (exocytosis) and/or phagosomal membranes (degranulation) [216]. Regulation of mobilization and targeting is incompletely defined, but in part involves (a) regulation of actin/cytoskeletal rearrangement, (b) calciumand/or ceramide-mediated signal transduction, and (c) soluble $\mathrm{N}$-ehtylmaleimide sensitive factor attaching proteins (SNAPs) and SNAP receptors (t-SNAREs) [70, 154]. Azurophilic (primary) and specific (secondary) granules are differentially targeted, owing to differences in cargo carried by each class of granule [70, 215]. Azurophilic granules containing a variety of pore-forming peptides $(\alpha$ defensins), proteases (proteinase-3, elastase), and other cytotoxic molecules (azurocidin, lysozyme, MPO), are targeted primarily to the phagosome, exposing ingested microbes to high concentrations of antimicrobial agents [215]. Specific (secondary) granules containing integral membrane components of the NADPH oxidase (flavocytochrome $\left.b_{558}\right)$ as well as some pore-forming peptides (cathelicidins) and cytotoxic molecules (lysozyme) are targeted to both the plasma membrane and the phagosome, serving the additional function of enriching the plasma membrane with critical components of the NADPH oxidase and surface molecules/receptors important for neutrophil response (integrins, chemotactic and opsonic receptors) [70, 215]. Specific granules also contain lactoferrin, an iron-binding protein which utilizes an additional, unique strategy against ingested microbes. Lactoferrin sequesters iron needed for microbial growth and also modulates Fenton-derived production of hydroxyl radical $[217,218]$. A similar strategy has been described for neutrophil calprotectin (S100A8/A9), which inhibits growth of $S$. aureus by sequestering nutrient $\mathrm{Mn}^{2+}$ and $\mathrm{Zn}^{2+}$ within abscesses [219]. The majority of microbicidal activity takes place within mature phagosomes. However secreted, extracellular molecules, namely the group IIA phospholipase $\mathrm{A}_{2}$ (gIIA-PLA $\mathrm{A}_{2}$ ), have been shown to act synergistically with neutrophil NADPH oxidase to promote digestion of $S$. aureus phospholipids, demonstrating collaboration between oxygen-dependent and oxygen-independent killing mechanisms [220].

In addition to ROS production and degranulation, a third neutrophil microbicidal mechanism has recently been proposed. Novel structures known as neutrophil extracellular traps (NETs), which contain decondensed chromatin, bound histones, azurophilic granule proteins, and cytosolic proteins, have a demonstrated capacity to bind to and kill a variety of pathogens including $S$. aureus [221]. Extrusion of such structures by neutrophils is predicted to limit microbial spread and dissemination, while enhancing effective concentrations of extruded microbicidal agents, thereby promoting synergistic killing of attached microorganisms [222]. It is debated whether extrusion of such structures is to be classified as a novel form of cell death or if these structures are extruded from live, intact cells. The phenomenon of NETosis has also been observed in other granulocyte cell types including mast cells and eosinophils $[222,223]$. The molecular basis of NET formation is yet poorly understood, although the process is directly linked to 
ROS production, as neutrophils from CGD patients, lacking functional NADPH oxidase, are unable to form NETs [224]. In vivo demonstrations of such structures have been provided by a limited number of human infectious and noninfectious diseases, as well as several animal infection models [222, 223]. It is not clear whether NETs alter the normal course of the inflammatory response or perhaps exacerbate inflammation. It has even been proposed that formation of NETs may contribute to autoimmune disorders [222]. The role of NETs in the innate immune response and our understanding of the mechanisms underlying this process remain incompletely defined and will require further research.

Neutrophil apoptosis and the resolution of inflammation

Turnover of immune cells is essential for maintenance and homeostasis of both innate and acquired immune systems, ensuring that cells working "out in the field" have sufficient functional capacity. Turnover is accomplished universally by the process of apoptosis or programmed cell death, which facilitates efficient, non-phlogistic removal of senescent or effete cells of all types [225, 226]. This process becomes increasingly critical for cells that carry high cytotoxic capacity and pro-inflammatory potential, such as neutrophils. Additionally, neutrophils are the most numerous leukocytes in humans, have a rapid rate of turnover, and critically function as first responders, further underscoring the importance of regulated, efficient removal of such cells in a manner that serves to prevent unnecessary host tissue damage and inflammation. Following apoptosis, which maintains neutrophil membrane integrity and prevents release of cytotoxic neutrophil contents, apoptotic neutrophils are recognized and ingested by macrophages without pro-inflammatory consequence, completing the turnover cycle. In the absence of stimulation, senescent neutrophils undergo spontaneous or constitutive apoptosis, a process initiated by signaling from within the cell, resulting in caspase activation and eventual removal by macrophages [227]. This intrinsic ability to undergo apoptosis is essential for maintaining appropriate cell numbers in circulation [228]. In the context of infection, where neutrophils are recruited to sites of infection, phagocytosis and subsequent neutrophil activation significantly accelerates apoptosis, a process known as phagocytosisinduced cell death (PICD) now thought to play a central role in resolution of the inflammatory response [106, 229, 230] (Fig. 2).

At the onset of infection, an influx of neutrophils to respective sites within tissues is driven by detection of a series of host- and/or bacterial-derived immunomodulatory factors that influence chemotactic movement and prime neutrophils for enhanced function. Many of these early pro-inflammatory signals have the additional ability to delay spontaneous neutrophil apoptosis, implying that increased survival of neutrophils is desirable early in the inflammatory process, perhaps promoting efficient pathogen recognition and removal [226, 231]. Additionally, phagocytic uptake of invading microorganisms induces a neutrophilmediated acute pro-inflammatory response, as evidenced in part by increased levels of transcripts involved in the acute inflammatory response [101]. More recently, it has become clear that phagocytosis of numerous pathogens, including $S$. aureus, significantly accelerates neutrophil apoptosis/PICD [232, 233]. Apoptosis ultimately leads to an overall decrease in cellular functions including a decreased ability to produce ROS, phagocytose, secrete cytokines, adhere, and chemotax [190, 234]. Concomitant to rapid induction of apoptosis is an accompanied downregulation of neutrophil pro-inflammatory capacity, illustrating the fine balance of signals required for effectively dealing with invaders and resolving acute inflammation [102, 190]. As apoptosis progresses, neutrophils undergo important cell surface changes including transposition of phosphatidylserine, oxidized lipids, and carbohydrate moieties to the external surface, marking apoptotic neutrophils for recognition by surface receptors on macrophages [235]. Recognition by macrophages leads subsequently to ingestion (efferocytosis) and non-phlogistic removal of apoptotic cells, as well as release of anti-inflammatory molecules, such as TGF- $\beta$ and IL-10 [103, 236-238] (Fig. 2). The importance of this removal process is highlighted by the redundancy of recognition receptors described for macrophages [101]. Mice lacking the macrophage receptor for phosphatidylserine accumulate apoptotic cells in the lung and brain, and develop autoimmune disorders [239, 240]. Thus, it is clear that neutrophil apoptosis plays a central role in desired resolution of the acute inflammatory response.

\section{S. aureus immune evasion mechanisms}

Many pathogens, including $S$. aureus, have a long history of interaction with the human innate immune system. Therefore, it is not surprising that many pathogens have evolved mechanisms to evade and combat this important front line of host defense. S. aureus has evolved an abundant repertoire of factors aimed at evasion of the innate system, including host defense strategies utilized by neutrophils. There exists significant redundancy in the numerous mechanisms employed by $S$. aureus against the innate immune system, reflecting the importance of such defenses and their role in the outcome of infection. $S$. aureus factors characterized to date include those that prevent recognition and binding of the pathogen by neutrophils, as well as those that provide protection against 
A

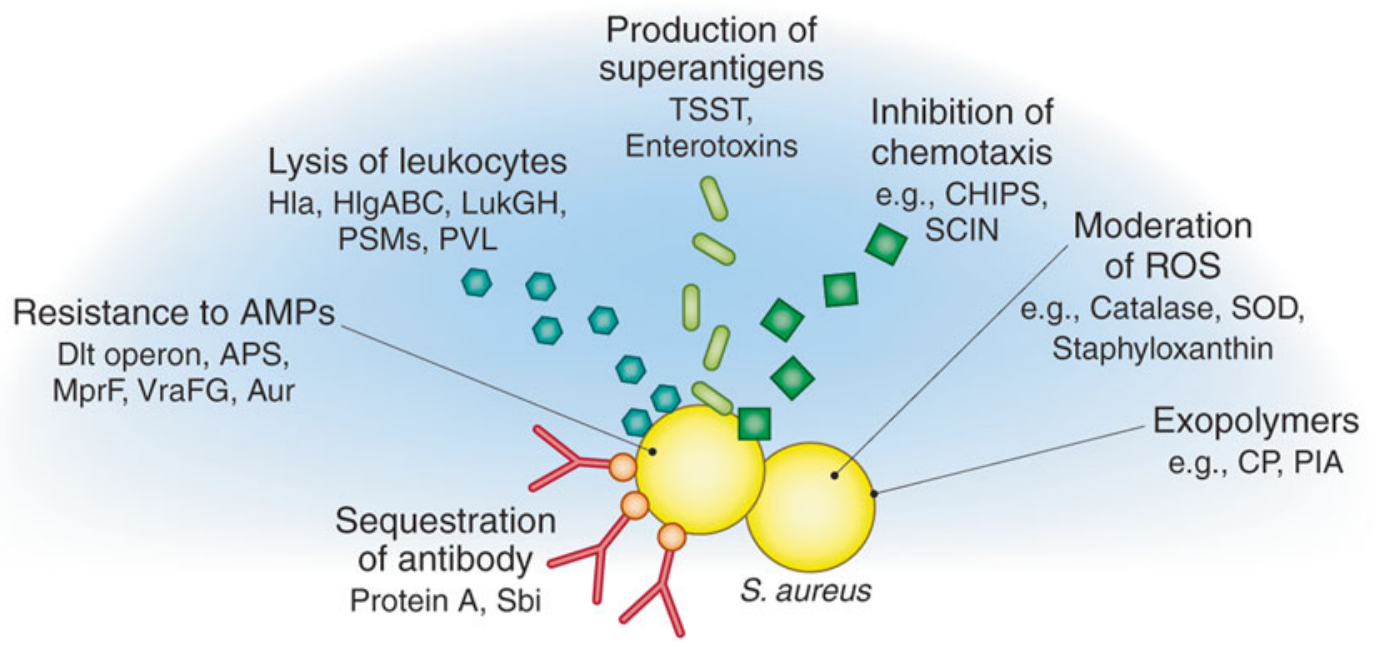

B

Killing of microbes

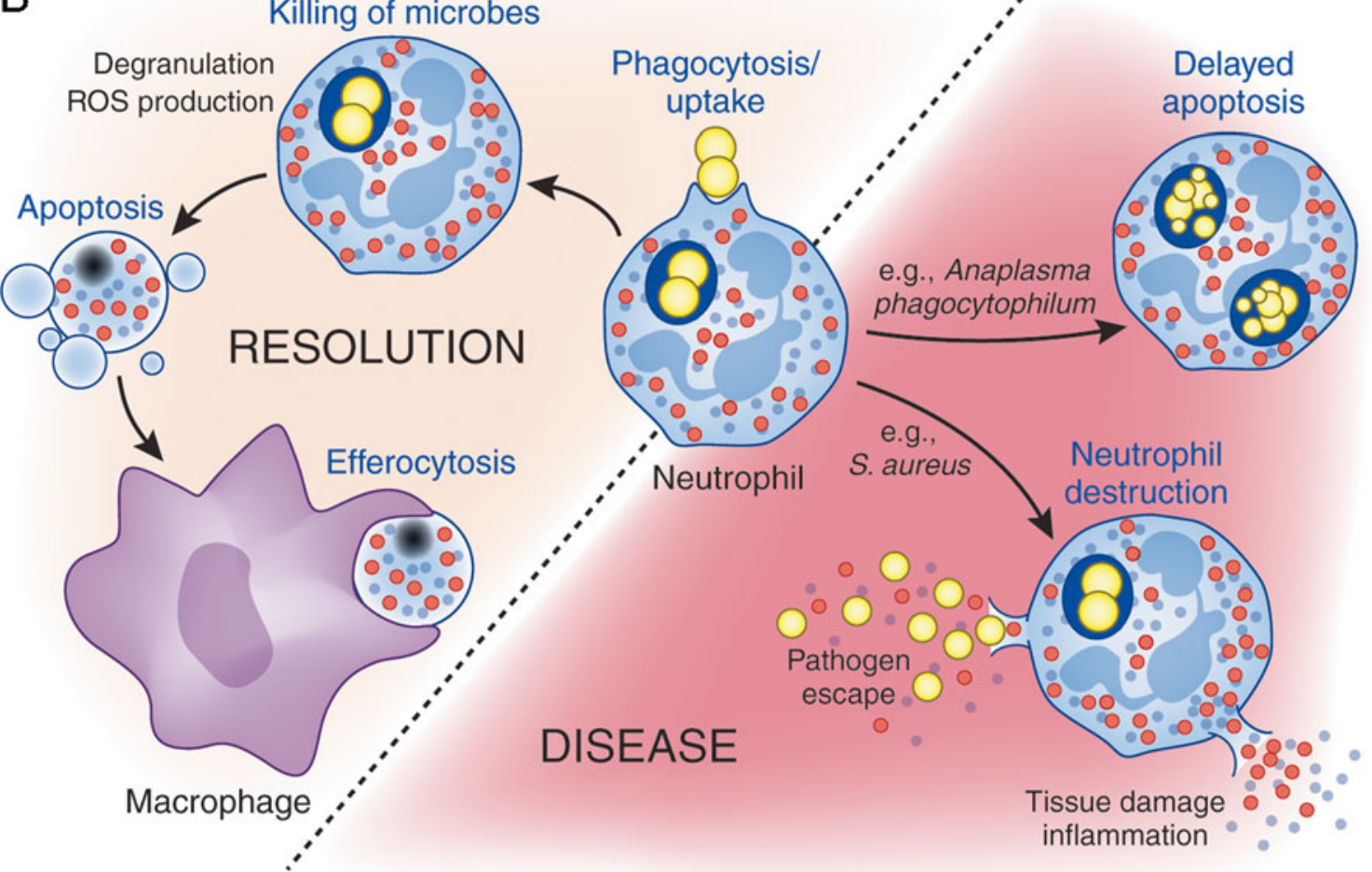

Fig. $2 S$. aureus immune evasion mechanisms and possible outcomes of bacteria-neutrophil interaction. A Immune evasion by $S$. aureus includes strategies that serve to prevent recognition, inhibit chemotaxis, moderate ROS, protect against AMPs, and directly damage immune cells. B Phagocytic uptake of bacteria triggers production of ROS and degranulation, working collectively to kill ingested bacteria, after which neutrophils undergo apoptosis to be removed by macrophages and promote healthy resolution of infection. Alternatively, bacterial pathogens can alter normal neutrophil turnover, promoting either a delay in neutrophil apoptosis or an accelerated neutrophil lysis. Alteration of

intracellular/phagosomal microbicides [10]. In addition to passive defense mechanisms, $S$. aureus secretes several cytotoxic molecules that have the ability to damage immune cells [10]. normal neutrophil turnover facilitates pathogen survival and promotion of disease. APS antimicrobial peptide-sensing system, Aur aureolysin, CHIPS chemotaxis inhibitory protein of $S$. aureus, $C P$ capsular polysaccharide, Hla $\alpha$-toxin, HlgABC $\gamma$-hemolysin, LukGH LukF-G and LukS-H, $M p r F$ multiple peptide resistance factor, PIA polysaccharide intercellular adhesion, $P S M S$ phenol-soluble modulins, $P V L$ Panton-Valentine leukocidin, Sbi second binding protein of immunoglobulin, $S C I N$ staphylococcal inhibitor of complement, $S O D$ superoxide dismutase, TSST toxic shock syndrome toxin, $\operatorname{VraFG}$ vancomycinresistant-associated gene, $\mathrm{ABC}$ transporter

S. aureus attempts to minimize or inhibit recognition by the host by hiding and/or modifying the bacterial surface. This is afforded by production of exopolymers such as capsular polysaccharide forming the bacterial capsule and/ 
or polysaccharide intercellular adhesion, a unique extracellular matrix biofilm component that serves to modify the typical negative charge of the bacterial outer surface [241244]. Additionally, the well-known protein A, which binds the $\mathrm{Fc}$ region of $\operatorname{IgG}$, lends the ability to coat the bacterial surface with non-specific antibodies (in the wrong orientation), providing immunologic disguise and potentially disrupting opsonization and phagocytic uptake [245, 246]. Chemotaxis inhibitory protein of $S$. aureus and staphylococcal complement inhibitor block receptor mediated recognition of $\mathrm{N}$-formyl peptides produced by bacteria and complement-mediated uptake, respectively [247, 248]. Curiously, despite the numerous mechanisms employed by $S$. aureus to inhibit binding and phagocytosis by neutrophils, these phagocytes rapidly take up the pathogen.

Protection against host oxygen-dependent microbicidal killing mechanisms is in part provided by catalase and superoxide dismutase, which eliminate harmful ROS produced within the phagosome following ingestion [13]. Staphyloxanthin is a golden pigment produced by $S$. aureus and has also been shown to play a protective role against ROS [249]. Mechanisms also exist for bacterial defense against oxygen-independent killing mechanisms, including those mediated by AMPs. In addition to releasing non-specific proteases [250], S. aureus senses the presence of AMPs via a three-component gene-regulatory system, which regulates downstream bacterial responses including the D-alanylation of teichoic acids and incorporation of lysyl-phosphatidyl glycerol in the plasma membrane, thereby decreasing overall negative charge of the bacterial surface [251-254]. These surface modifications reduce the efficiency of the binding of cationic AMPs to the bacterial surface. Furthermore, the VraFG transporter is responsible for the removal of AMPs from the cytoplasm or plasma membrane [251, 252]. In addition to these rather passive defense mechanisms, $S$. aureus produces a number of toxins that directly attack white and red blood cells. Such toxins include a family of leukocidins, $\alpha$-toxin ( $\alpha$-hemolysin), and the recently described PSMs. These molecules have the ability to form pores in target cell membranes [152, 255]. Lastly, several types of secreted $S$. aureus toxins are also classified as superantigens, taking the strategy of overstimulating the immune response to potentiate undesired responses and cause disease [256, 257]. Examples of superantigenic toxins include TSST and staphylococcal enterotoxins [257].

It is evident that apoptosis plays a major role in the resolution of the acute inflammatory response, likely having an impact on the outcome of disease. That being said, some pathogens have also devised means to modulate normal turnover and apoptosis of neutrophils, leading to alterations in the desired resolution of infection [226] (Fig. 2). Although the short life-span of neutrophils is not conducive to the long-term survival strategies employed by many intracellular pathogens, Anaplasma phagocytophilum, the causative agent of human granulocytic anaplasmosis, has the ability to delay neutrophil apoptosis, supporting replication and survival of the pathogen within an endosomal compartment $[189,226,258]$. On the other hand, S. aureus, especially CA-MRSA strains, have the remarkable ability to induce rapid lysis of neutrophils and/ or accelerate PICD to the point of secondary lysis, potentiating undesired release of neutrophil contents and pathogen survival $[71,72,102,226]$. In either case, modulation of the normal turnover process results in pathogen survival, promotion of pathogenesis, and likely dissemination and disease (Fig. 2).

\section{Community MRSA virulence and evasion of killing by neutrophils}

The increased virulence of CA-MRSA strains was initially inferred from (a) the ability of these strains to cause disease in otherwise healthy individuals, (b) the ability of these strains to cause unusually severe disease, and (c) their ability to spread rapidly among groups of individuals. Corroborating the epidemiologic data, experimental data have demonstrated conclusively that CA-MRSA strains are more virulent than representative HA-MRSA strains in animal models of infection [71, 72]. Increased virulence is attributed largely to an enhanced capacity of CA-MRSA strains to resist killing by neutrophils, compared to HAMRSA strains [72]. Survival of CA-MRSA strains in in vitro assays with human neutrophils leads to rapid lysis of these host cells, and release and ultimate growth of bacteria $[72,259]$. This follows with the idea that increased virulence lies, at least in part, in the enhanced ability to alter normal neutrophil function and turnover.

Early distinction of CA-MRSA strains from traditional HA-MRSA strains, which included differences in PFGE typing and antibiotic resistance profiles, suggested that CAMRSA strains were not merely hospital strains that had escaped into the community. Therefore, efforts to understand the molecular basis of the enhanced virulence of CAMRSA strains have since focused on identifying additional genotypic and phenotypic differences between CA-MRSA and traditional HA-MRSA strains. Although significant progress has been made in understanding components that contribute to the success of CA-MRSA, a complete understanding is complicated by the multi-factorial approach to virulence that is intrinsic to $S$. aureus. That is, no single virulence factor contributes exclusively, making it difficult to determine contributions made by individual components that have overlapping or redundant functions. Despite this obstacle, several $S$. aureus virulence determinants are implicated in the success of CA-MRSA. 
Alpha ( $\alpha$ )-toxin (also known as Hla or $\alpha$-hemolysin) is a widely studied pore-forming toxin capable of destroying a variety of host cells, including epithelial cells, erythrocytes, fibroblasts, monocytes, macrophages, and lymphocytes (but not neutrophils), and has long been considered a major virulence determinant of $S$. aureus $[260,261]$. Although it is ubiquitous among clinical isolates, recent studies have clearly demonstrated a primary role for $\alpha$-toxin in experimental CA-MRSA infections. CA-MRSA strains lacking $\alpha$-toxin were avirulent in a murine pneumonia model of infection compared with isogenic wild-type strains, and active and passive immunization against $\alpha$-toxin provided animals protection from death in the same model $[262,263]$. Mechanistically, $\alpha$-toxin elicits a host chemokine response in the murine pneumonia model, promoting an influx of neutrophils thought to be largely responsible for lung injury during infection [264]. Importantly, the amount of $\alpha$-toxin produced by CA-MRSA in vitro correlates with the severity of lung disease observed in such animal models $[262,265,266]$. The role of $\alpha$-toxin has also been demonstrated in murine and rabbit models of CA-MRSA skin infection, providing further evidence that $\alpha$-toxin plays a major role in CA-MRSA disease [267, 268].

$\alpha$-Type phenol-soluble modulins ( $\alpha$-PSMs) are a subset of recently reported PSMs [152]. These molecules are surfactant-like, amphipathic, $\alpha$-helical peptides $(\sim 20-25$ aa in length) with limited homology to PSMs produced in other staphylococcal species including Staphylococcus epidermidis [152]. The $\alpha$-PSMs are ubiquitous to all sequenced $S$. aureus strains, have the ability to induce neutrophil chemotaxis and cytokine release through a specific receptor-mediated process, and also have the ability to lyse neutrophils, erythrocytes, and monocytes via a receptor-independent process [152]. Isogenic mutant CAMRSA strains that lack $\alpha$-PSMs have significantly reduced virulence in murine bacteremia and skin infection models compared to wild-type parental strains, indicating they are major determinants of CA-MRSA virulence [152]. Notably, in vitro production of $\alpha$-PSMs by CA-MRSA strains is significantly higher than that of prominent HA-MRSA strains. Additionally, overexpression of $\alpha$-PSMs in a representative HA-MRSA strain increases cytotoxic capacity of culture supernatants to a level comparable to that observed with CA-MRSA culture supernatants, indicating that the difference in cytolytic capacity between CA-MRSA and HA-MRSA strains is largely due to differential production of $\alpha$-PSMs [152]. However, the contribution of $\alpha$-PSMs to neutrophil lysis following phagocytosis remains to be determined. Production of $\alpha$-PSMs is regulated in part by the accessory gene regulator (agr), a well-known, global regulatory/quorum sensing system. $\alpha$-Toxin and $\alpha$-PSMs are both encoded in the core genome, as opposed to mobile genetic elements (MGEs), which encode many other $S$. aureus virulence molecules. Recent analysis of gene expression within subclones of $S$. aureus clonal complex 8 (defined by MLST), including USA300 and other closely related strains, revealed that USA300 has increased expression of core-genome encoded virulence factors such as $\alpha$-toxin and $\alpha$-PSMs, lending to the novel idea that enhanced virulence is based largely on differential expression of core-genome elements rather than strictly acquisition of MGEs [269]. Differential expression of core-genome determinants is likely due to poorly understood rearrangements of gene regulatory networks in these strains.

It is likely that the extraordinary success of CA-MRSA also involves unique genetic factors that facilitate colonization and transmissibility. Although such factors may not contribute directly to virulence, they may be important for the overall burden of disease, as seen with the rapid dissemination of CA-MRSA among groups of individuals. One such factor is the type-I arginine catabolic mobile element (ACME), an MGE unique to USA300, identified by whole genome sequencing [270]. This 31-kb MGE is physically linked to the SCCmec type IV element and may have been acquired from S. epidermidis $[67,270]$. ACME encodes two gene clusters, one encoding a complete arginine deiminase ( $a r c$ ) pathway, and the other an oligopeptide permease operon. Arginine deiminase activity produces ammonia and ATP and might facilitate colonization by neutralizing the acidic environment found on skin as well as producing an additional source of ATP [67]. In addition, depletion of the arginine pool may serve to prevent efficient production of nitric oxide, a key immune molecule [271]. Oligopeptide permeases are usually involved in peptide uptake as a nutrient source, although they are also implicated in other functions such as quorum sensing, chemotaxis, cell adhesion, and resistance to AMPs [270]. Experimental models of infection have demonstrated either no impact or a limited impact of ACME on virulence [67, 272]. Although a function related to enhanced colonization and/or persistence on human skin, leading to increased transmissibility, has been inferred from the putative functions of genes found within ACME, the physiologic function of these gene clusters in the context of CA-MRSA pathogenesis remains to be determined. This will require experimental colonization models to directly assess any role ACME may play in the colonization, persistence, and/or transmissibility of CA-MRSA.

Panton-Valentine leukocidin (PVL) is a bi-component cytolytic toxin encoded on a prophage acquired by horizontal gene transfer [273]. PVL has the ability to prime neutrophils, induce proinflammatory responses such as cytokine release, and has long been known, at higher concentrations, to lyse leukocytes by forming pores in target-cell membranes [42, 274-279]. PVL genes are 
present in many strains that cause CA-MRSA infections, and the toxin is associated with $S$. aureus strains that cause certain types of severe skin infections (e.g., furuncles and carbuncles) and necrotizing pneumonia [42, 280-282]. It is noteworthy that PVL was also present in the pandemic phage-type 80/81 clone, which caused severe infections in hospitals and the community in the 1950s and 1960s [283]. Therefore, elucidating the role for PVL (if any) in the success of CA-MRSA has been of great interest and remains a hotly debated topic in light of many experimental studies, some of which are conflicting. Numerous animal models of infection have been utilized to investigate PVL's contribution during CA-MRSA infections including murine, rat, rabbit, and non-human primate models of skin infection, bacteremia, and pneumonia [11-13, 17]. Generally, findings from studies to date indicate that PVL makes little or no unique contribution to the virulence of CAMRSA, but may contribute in specific contexts resulting in severe diseases or syndromes [12, 71, 284-288]. Due to that fact that PVL production is sensitive to environmental conditions (e.g., growth media) and is strain dependent, as well as the fact that the susceptibility of white blood cells to PVL differs among mammalian species, it is not surprising that conflicting findings have been reported [289, 290]. Recently Kobayashi et al. investigated the role of PVL in a novel rabbit subcutaneous skin infection model, reporting that a USA300 wild-type and isogenic lukS/F-PV deletion strains produced similar abscesses, whereas deletion of genes encoding other well-established virulence determinants- $\alpha$-toxin, $\alpha$-PSMs, and Agr-decreased abscess formation [267]. Concurrently, a rabbit intradermal skin infection model was published using similar strains, but these authors reported a role for PVL in pathogenesis of $S$. aureus skin infection [291]. These seemingly contradictory findings highlight the possibility that PVL functions in specific experimental contexts, and emphasizes the need for careful interpretation and comparison among experimental models used. Taken together, evidence to date indicates that PVL is not a major virulence determinant of CA-MRSA, but is simply one of many $S$. aureus secreted molecules that can contribute to infection.

A recent surface proteome study of USA300 identified an abundant, novel two-component leukotoxin, LukGH, related to other two-component toxins of $S$. aureus such as PVL [292]. LukGH is localized to the cell surface and is secreted into culture medium. Importantly, LukGH has potent cytolytic activity toward neutrophils, acts synergistically with PVL to cause neutrophil lysis in vitro, and is highly expressed during phagocytosis. These results suggest LukGH contributes to USA300 virulence [292]. Further investigation is required to demonstrate a physiologic role for LukGH in the ability to cause disease.

\section{Neutrophil defects and $S$. aureus infections}

Acquired and congenital defects of the immune system are associated with an increased susceptibility to infectious disease. Description of numerous primary immunodeficiency diseases (PIDs), defined here as a genetically determined disorder resulting in an enhanced susceptibility to infectious disease, has served to bolster the importance of many human immune functions, including the role of neutrophils in defense against bacterial pathogens such as $S$. aureus [209, 293-295]. PIDs are broadly classified based on their underlying molecular defect and include deficiencies in humoral immunity (B lymphocytes, antibodies), cellmediated immunity ( $\mathrm{T}$ cell-mediated), combined humoral and cell-mediated immunity, and non-specific host defense (phagocytes, natural killer cells, complement pathway). PIDs characteristically present in childhood with persistent, recurrent, and difficult to treat infections. Importantly, pathogen susceptibility patterns, sites of infection, and complications of infection are known to vary according to immune deficit, and are major considerations made during diagnosis [293, 295]. Each class of primary immunodeficiency has a characteristic set of infectious predispositions that are often employed to guide initial diagnostic testing [293]. Defects in T cell function are generally associated with infections caused by viruses and Candida species, whereas patients with primary phagocyte defects yield an increased susceptibility to specific bacterial and fungal infections [209]. In some cases, pathogen susceptibility points to the specific disorder; susceptibility to intracellular pathogens such as mycobacteria, Salmonella, and Listeria is suggestive of a defect in the interferon- $\gamma$-interleukin-12 signaling axis [209], while infections caused by $S$. aureus and Aspergillus species predominate among patients with CGD [293].

Several PIDs have been described for a range of underlying primary neutrophil defects, including functional defects in neutrophil adhesion, chemotaxis, phagocytosis, vesicle trafficking, NADPH oxidase assembly/function, MPO deficiency, glucose/glycogen metabolism, signal transduction, and granular defects [70]. Many of these defects are closely associated with increased susceptibility to $S$. aureus infections, and often result in life-threatening and/or fatal complications. Severe congenital neutropenia (SCN) is associated with mutations from two different genes; mutation in HAX1, a mitochondrial protein thought to have an anti-apoptotic role, is associated with an autosomal dominant form of SCN, while mutation of ELA2, the gene encoding elastase 2, is associated with an autosomal recessive SCD resulting from endoplasmic reticulum (ER) stress, unfolded protein response (UPR), and apoptosis [70]. Infectious complications arising in SCN patients include cellulitis, perirectal abscesses, peritonitis, 
stomatitis, and meningitis commonly resulting from infections caused by $S$. aureus and Pseudomonas aeruginosa [209, 296]. Leukocyte adhesion deficiency types 1 and 2 (LAD1 and 2) are caused by defects in adhesion molecules such as $\mathrm{CD} 18$ ( $\beta_{2}$ integrin; LAD1) or an inability to fucosylate glycoproteins acting as ligands for E-selectins (LAD2), respectively [209, 293, 295]. As a result of their inability to make initial attachment, or adhere tightly to endothelial cells, neutrophils are unable to egress from the vasculature to sites of infection [209, 293]. Clinical manifestations include delayed separation of the umbilical cord, poor wound healing, recurrent skin and soft-tissue infections, genital mucosa infections, intestinal and respiratory tract infections, and severe periodontitis. Infecting pathogens include $S$. aureus, Gram-negative enteric bacteria, Candida species, and Aspergillus species [209]. Chédiak-Higashi syndrome is a disorder caused by mutations that affect the lysosomal transport protein LYST, and thus prevents normal phagolysosome formation and granule fusion $[209,293,295]$. This syndrome is partly characterized by recurrent, severe $S$. aureus infections. Other neutrophil disorders associated with $S$. aureus infections include neutrophil-specific granule deficiency and hyper-IgE syndrome (Job's syndrome) [209, 293]. Importantly, some of these neutrophil disorders may involve defects in regulation of neutrophil apoptosis and/or turnover. Taken together, neutrophil function plays a major role in clearance of invading bacterial pathogens such as $S$. aureus.

\section{Summary and outlook}

S. aureus remains a major cause of human infections, and the rise of highly virulent, drug-resistant strains has made treatment increasingly difficult. As a result, the overall burden of disease has increased within both the hospital and community settings, emphasizing the need for alternative therapeutic approaches. Although progress has been made toward understanding mechanisms used by $S$. aureus to evade innate host defenses, especially those involving neutrophils, our knowledge in this area is incomplete. The ability of $S$. aureus to evade primary host defenses plays a major role in the outcome of infection, as evidenced by the enhanced ability of CA-MRSA to evade and combat innate immunity and ultimately destroy neutrophils. This process likely contributes to the enhanced virulence of prominent CA-MRSA strains and their capacity to cause severe disease in otherwise healthy individuals. Therefore, a comprehensive understanding of the interface between innate host defense and $S$. aureus is needed to identify alternative therapeutic approaches. Underlying host genetic factors are likely important determinants of susceptibility to severe disease and must also be considered for development of alternative treatments.
Renewed efforts- fueled by the rise of antibiotic-resistant strains - to develop vaccines that promote opsonophagocytosis of $S$. aureus have not been successful. The problem is twofold. First, S. aureus opsonized in normal human serum is readily phagocytosed by human neutrophils and there is no need to improve efficiency of uptake, which is the primary purpose of opsonophagocytic vaccines. Second, S. aureus, especially CA-MRSA, causes lysis of neutrophils following phagocytosis [297, 298]. This is a significant problem because, as stated above, neutrophils are the most prominent cellular defense against $S$. aureus infections. Ideally, a therapeutic maneuver would enhance the killing capacity of neutrophils after uptake of the pathogen or render $S$. aureus incapable of defending itself against microbicides produced by neutrophils. Novel approaches to target virulence as a means of attenuating disease are underway and include strategies such as passive immunization with antibodies against main virulence determinants of S. aureus [299]. Some potential targets have been provided by identification of virulence determinants of CA-MRSA, including $\alpha$-toxin and $\alpha$-PSMs. For example, passive immunization with anti- $\alpha$-toxin antibodies provides protection against lethal pneumonia in a murine model of infection, demonstrating the potential utility of such therapy as an adjunct to antibiotic administration [263]. However, much functional redundancy exists among the numerous $S$. aureus virulence determinants, requiring a combinatorial therapeutic approach that includes targeting the most important virulence determinants. Therefore, elucidation of the contribution of host factors, as well as the major bacterial virulence determinants, to the development of severe disease is of major interest to future research.

Acknowledgments The authors are supported by the Intramural Research Program of the National Institute of Allergy and Infectious Diseases, National Institutes of Health.

Open Access This article is distributed under the terms of the Creative Commons Attribution Noncommercial License which permits any noncommercial use, distribution, and reproduction in any medium, provided the original author(s) and source are credited.

\section{References}

1. Smith G (1982) Ogston's coccus: 102 years and still going strong. South Med J 75(12):1559-1562

2. Newsom SW (2008) Ogston's coccus. J Hosp Infect 70(4):369-372

3. Diekema DJ, Pfaller MA, Schmitz FJ, Smayevsky J, Bell J, Jones RN, Beach M (2001) Survey of infections due to Staphylococcus species: frequency of occurrence and antimicrobial susceptibility of isolates collected in the United States, Canada, Latin America, Europe, and the Western Pacific region for the SENTRY Antimicrobial Surveillance Program, 19971999. Clin Infect Dis 32(Suppl 2):S114-S132

4. Styers D, Sheehan DJ, Hogan P, Sahm DF (2006) Laboratorybased surveillance of current antimicrobial resistance patterns 
and trends among Staphylococcus aureus: 2005 status in the United States. Ann Clin Microbiol Antimicrob 5:2

5. Klevens RM, Morrison MA, Nadle J, Petit S, Gershman K, Ray S, Harrison LH, Lynfield R, Dumyati G, Townes JM, Craig AS, Zell ER, Fosheim GE, McDougal LK, Carey RB, Fridkin SK (2007) Invasive methicillin-resistant Staphylococcus aureus infections in the United States. JAMA 298(15):1763-1771

6. Lowy FD (1998) Staphylococcus aureus infections. N Engl J Med 339(8):520-532

7. Klein E, Smith DL, Laxminarayan R (2007) Hospitalizations and deaths caused by methicillin-resistant Staphylococcus aureus, United States, 1999-2005. Emerg Infect Dis 13(12): $1840-1846$

8. Noskin GA, Rubin RJ, Schentag JJ, Kluytmans J, Hedblom EC, Jacobson C, Smulders M, Gemmen E, Bharmal M (2007) National trends in Staphylococcus aureus infection rates: impact on economic burden and mortality over a 6-year period (19982003). Clin Infect Dis 45(9):1132-1140

9. Gorwitz RJ, Kruszon-Moran D, McAllister SK, McQuillan G, McDougal LK, Fosheim GE, Jensen BJ, Killgore G, Tenover FC, Kuehnert MJ (2008) Changes in the prevalence of nasal colonization with Staphylococcus aureus in the United States, 2001-2004. J Infect Dis 197(9):1226-1234

10. Foster TJ (2005) Immune evasion by staphylococci. Nat Rev Microbiol 3(12):948-958

11. Otto M (2010) Basis of virulence in community-associated methicillin-resistant Staphylococcus aureus. Annu Rev Microbiol 64:143-162

12. Deleo FR, Otto M, Kreiswirth BN, Chambers HF (2010) Community-associated methicillin-resistant Staphylococcus aureus. Lancet 375(9725):1557-1568

13. DeLeo FR, Diep BA, Otto M (2009) Host defense and pathogenesis in Staphylococcus aureus infections. Infect Dis Clin North Am 23(1):17-34

14. Lowy FD (2003) Antimicrobial resistance: the example of Staphylococcus aureus. J Clin Invest 111(9):1265-1273

15. Rammelkamp CH, Maxon T (1942) Resistance of Staphylococcus aureus to the action of penicillin. Proc Soc Exp Biol Med 51 (3):386-389

16. Barber M, Rozwadowskadowzenko M (1948) Infection by penicillin-resistant staphylococci. Lancet 255(OCT23):641644

17. Chambers HF, DeLeo FR (2009) Waves of resistance: Staphylococcus aureus in the antibiotic era. Nat Rev Microbiol 7 (9):629-641

18. DeLeo FR, Chambers HF (2009) Reemergence of antibioticresistant Staphylococcus aureus in the genomics era. J Clin Invest 119(9):2464-2474

19. Graves SF, Kobayashi SD, DeLeo FR (2010) Communityassociated methicillin-resistant Staphylococcus aureus immune evasion and virulence. J Mol Med 88(2):109-114

20. Barber M (1961) Methicillin-resistant staphylococci. J Clin Pathol 14:385-393

21. Jevons MP, Rolinson GN, Knox R (1961) Celbenin-resistant staphylococci. Brit Med J 1(521):124

22. Voss A, Milatovic D, Wallrauch-Schwarz C, Rosdahl VT, Braveny I (1994) Methicillin-resistant Staphylococcus aureus in Europe. Eur J Clin Microbiol Infect Dis 13(1):50-55

23. Klevens RM, Edwards JR, Tenover FC, McDonald LC, Horan T, Gaynes R (2006) Changes in the epidemiology of methicillinresistant Staphylococcus aureus in intensive care units in US hospitals, 1992-2003. Clin Infect Dis 42(3):389-391

24. Jarvis WR, Schlosser J, Chinn RY, Tweeten S, Jackson M (2007) National prevalence of methicillin-resistant Staphylococcus aureus in inpatients at US health care facilities, 2006. Am J Infect Control 35(10):631-637
25. Heron MP, Hoyert DL, Xu J, Scott C, Tejada-Vera B (2008) Deaths: preliminary data for 2006. Natl Vital Stat Rep 56:1-52

26. Pantosti A, Sanchini A, Monaco M (2007) Mechanisms of antibiotic resistance in Staphylococcus aureus. Future Microbiol 2(3):323-334

27. David MZ, Daum RS (2010) Community-associated methicillinresistant Staphylococcus aureus: epidemiology and clinical consequences of an emerging epidemic. Clin Microbiol Rev 23 (3):616-687

28. Maranan MC, Moreira B, Boyle-Vavra S, Daum RS (1997) Antimicrobial resistance in staphylococci. Epidemiology, molecular mechanisms, and clinical relevance. Infect Dis Clin North Am 11(4):813-849

29. Herold BC, Immergluck LC, Maranan MC, Lauderdale DS, Gaskin RE, Boyle-Vavra S, Leitch CD, Daum RS (1998) Community-acquired methicillin-resistant Staphylococcus aureus in children with no identified predisposing risk. JAMA 279 (8):593-598

30. Aiello AE, Lowy FD, Wright LN, Larson EL (2006) Meticillinresistant Staphylococcus aureus among US prisoners and military personnel: review and recommendations for future studies. Lancet Infect Dis 6(6):335-341

31. Adcock PM, Pastor P, Medley F, Patterson JE, Murphy TV (1998) Methicillin-resistant Staphylococcus aureus in two child care centers. J Infect Dis 178(2):577-580

32. Diep BA, Chambers HF, Graber CJ, Szumowski JD, Miller LG, Han LL, Chen JH, Lin F, Lin J, Phan TH, Carleton HA, McDougal LK, Tenover FC, Cohen DE, Mayer KH, Sensabaugh GF, Perdreau-Remington F (2008) Emergence of multidrugresistant, community-associated, methicillin-resistant Staphylococcus aureus clone USA300 in men who have sex with men. Ann Intern Med 148(4):249-257

33. Begier EM, Frenette K, Barrett NL, Mshar P, Petit S, Boxrud DJ, Watkins-Colwell K, Wheeler S, Cebelinski EA, Glennen A, Nguyen D, Hadler JL (2004) A high-morbidity outbreak of methicillin-resistant Staphylococcus aureus among players on a college football team, facilitated by cosmetic body shaving and turf burns. Clin Infect Dis 39(10):1446-1453

34. Barr B, Felkner M, Diamond PM (2006) High school athletic departments as sentinel surveillance sites for communityassociated methicillin-resistant staphylococcal infections. Tex Med 102:56-61

35. Kazakova SV, Hageman JC, Matava M, Srinivasan A, Phelan L, Garfinkel B, Boo T, McAllister S, Anderson J, Jensen B, Dodson D, Lonsway D, McDougal LK, Arduino M, Fraser VJ, Killgore G, Tenover FC, Cody S, Jernigan DB (2005) A clone of methicillin-resistant Staphylococcus aureus among professional football players. N Engl J Med 352(5):468-475

36. Coronado F, Nicholas JA, Wallace BJ, Kohlerschmidt DJ, Musser K, Schoonmaker-Bopp DJ, Zimmerman SM, Boller AR, Jernigan DB, Kacica MA (2007) Community-associated methicillin-resistant Staphylococcus aureus skin infections in a religious community. Epidemiol Infect 135(3):492-501

37. Fontanilla JM, Kirkland KB, Talbot EA, Powell KE, Schwartzman JD, Goering RV, Parsonnet J (2010) Outbreak of skin infections in college football team members due to an unusual strain of community-acquired methicillin-susceptible Staphylococcus aureus. J Clin Microbiol 48(2):609-611

38. Jail LAC, Svcs LACDH (2003) Public health dispatch: Outbreaks of community-associated methicillin-resistant Staphylococcus aureus skin infections - Los Angeles County, California, 2002-2003 (Reprinted from MMWR, vol 52, pg 88, 2003). Jama J Am Med Assoc 289(11):1377

39. Campbell KM, Vaughn AF, Russell KL, Smith B, Jimenez DL, Barrozo CP, Minarcik JR, Crum NF, Ryan MA (2004) Risk factors for community-associated methicillin-resistant Staphylo- 
coccus aureus infections in an outbreak of disease among military trainees in San Diego, California, in 2002. J Clin Microbiol 42(9):4050-4053

40. Outbreaks of community-associated methicillin-resistant Staphylococcus aureus skin infections-Los Angeles County, California, 2002-2003 (2003). MMWR Morb Mortal Wkly Rep 52(5):88

41. Crum NF, Lee RU, Thornton SA, Stine OC, Wallace MR, Barrozo C, Keefer-Norris A, Judd S, Russell KL (2006) Fifteenyear study of the changing epidemiology of methicillin-resistant Staphylococcus aureus. Am J Med 119(11):943-951

42. Vandenesch F, Naimi T, Enright MC, Lina G, Nimmo GR, Heffernan H, Liassine N, Bes M, Greenland T, Reverdy ME, Etienne J (2003) Community-acquired methicillin-resistant Staphylococcus aureus carrying Panton-Valentine leukocidin genes: worldwide emergence. Emerg Infect Dis 9(8):978-984

43. Deurenberg RH, Nulens E, Valvatne H, Sebastian S, Driessen C, Craeghs J, De Brauwer E, Heising B, Kraat YJ, Riebe J, Stals FS, Trienekens TA, Scheres J, Friedrich AW, van Tiel FH, Beisser PS, Stobberingh EE (2009) Cross-border dissemination of methicillinresistant Staphylococcus aureus, Euregio Meuse-Rhin region. Emerg Infect Dis 15(5):727-734

44. Huang YC, Hwang KP, Chen PY, Chen CJ, Lin TY (2007) Prevalence of methicillin-resistant Staphylococcus aureus nasal colonization among Taiwanese children in 2005 and 2006. J Clin Microbiol 45(12):3992-3995

45. Nimmo GR, Coombs GW (2008) Community-associated methicillin-resistant Staphylococcus aureus (MRSA) in Australia. Int J Antimicrob Agents 31(5):401-410

46. Park SH, Park C, Yoo JH, Choi SM, Choi JH, Shin HH, Lee DG, Lee S, Kim J, Choi SE, Kwon YM, Shin WS (2009) Emergence of community-associated methicillin-resistant Staphylococcus aureus strains as a cause of healthcare-associated bloodstream infections in Korea. Infect Control Hosp Epidemiol 30(2):146-155

47. Gardella N, von Specht M, Cuirolo A, Rosato A, Gutkind G, Mollerach M (2008) Community-associated methicillin-resistant Staphylococcus aureus, eastern Argentina. Diagn Microbiol Infect Dis 62(3):343-347

48. Francois P, Harbarth S, Huyghe A, Renzi G, Bento M, Gervaix A, Pittet D, Schrenzel J (2008) Methicillin-resistant Staphylococcus aureus, Geneva, Switzerland, 1993-2005. Emerg Infect Dis 14(2):304-307

49. Fang H, Hedin G, Li G, Nord CE (2008) Genetic diversity of community-associated methicillin-resistant Staphylococcus aureus in southern Stockholm, 2000-2005. Clin Microbiol Infect 14 (4):370-376

50. Conly JM, Johnston BL (2003) The emergence of methicillinresistant Staphylococcus aureus as a community-acquired pathogen in Canada. Can J Infect Dis 14(5):249-251

51. Laupland KB, Ross T, Gregson DB (2008) Staphylococcus aureus bloodstream infections: risk factors, outcomes, and the influence of methicillin resistance in Calgary, Canada, 2000 2006. J Infect Dis 198(3):336-343

52. Moran GJ, Krishnadasan A, Gorwitz RJ, Fosheim GE, McDougal LK, Carey RB, Talan DA (2006) Methicillin-resistant S. aureus infections among patients in the emergency department. N Engl J Med 355(7):666-674

53. Kaplan SL, Hulten KG, Gonzalez BE, Hammerman WA, Lamberth L, Versalovic J, Mason EO Jr (2005) Three-year surveillance of community-acquired Staphylococcus aureus infections in children. Clin Infect Dis 40(12):1785-1791

54. Mathews WC, Caperna JC, Barber RE, Torriani FJ, Miller LG, May S, McCutchan JA (2005) Incidence of and risk factors for clinically significant methicillin-resistant Staphylococcus aureus infection in a cohort of HIV-infected adults. J Acquir Immune Defic Syndr 40(2):155-160
55. Purcell K, Fergie J (2005) Epidemic of community-acquired methicillin-resistant Staphylococcus aureus infections: a 14-year study at Driscoll Children's Hospital. Arch Pediatr Adolesc Med 159(10):980-985

56. Fridkin SK, Hageman JC, Morrison M, Sanza LT, Como-Sabetti K, Jernigan JA, Harriman K, Harrison LH, Lynfield R, Farley MM (2005) Methicillin-resistant Staphylococcus aureus disease in three communities. N Engl J Med 352(14):1436-1444

57. Liu C, Graber CJ, Karr M, Diep BA, Basuino L, Schwartz BS, Enright MC, O'Hanlon SJ, Thomas JC, Perdreau-Remington F, Gordon S, Gunthorpe H, Jacobs R, Jensen P, Leoung G, Rumack JS, Chambers HF (2008) A population-based study of the incidence and molecular epidemiology of methicillin-resistant Staphylococcus aureus disease in San Francisco, 2004-2005. Clin Infect Dis 46(11):1637-1646

58. Miller LG, Perdreau-Remington F, Rieg G, Mehdi S, Perlroth J, Bayer AS, Tang AW, Phung TO, Spellberg B (2005) Necrotizing fasciitis caused by community-associated methicillin-resistant Staphylococcus aureus in Los Angeles. N Engl J Med 352 (14):1445-1453

59. Kallen AJ, Brunkard J, Moore Z, Budge P, Arnold KE, Fosheim G, Finelli L, Beekmann SE, Polgreen PM, Gorwitz R, Hageman J (2009) Staphylococcus aureus community-acquired pneumonia during the 2006 to 2007 influenza season. Ann Emerg Med 53 (3):358-365

60. Francis JS, Doherty MC, Lopatin U, Johnston CP, Sinha G, Ross T, Cai M, Hansel NN, Perl T, Ticehurst JR, Carroll K, Thomas DL, Nuermberger E, Bartlett JG (2005) Severe community-onset pneumonia in healthy adults caused by methicillin-resistant Staphylococcus aureus carrying the Panton-Valentine leukocidin genes. Clin Infect Dis 40(1):100-107

61. Gonzalez BE, Hulten KG, Dishop MK, Lamberth LB, Hammerman WA, Mason EO Jr, Kaplan SL (2005) Pulmonary manifestations in children with invasive community-acquired Staphylococcus aureus infection. Clin Infect Dis 41(5):583-590

62. Hageman JC, Uyeki TM, Francis JS, Jernigan DB, Wheeler JG, Bridges CB, Barenkamp SJ, Sievert DM, Srinivasan A, Doherty MC, McDougal LK, Killgore GE, Lopatin UA, Coffman R, MacDonald JK, McAllister SK, Fosheim GE, Patel JB, McDonald LC (2006) Severe community-acquired pneumonia due to Staphylococcus aureus, 2003-04 influenza season. Emerg Infect Dis 12(6):894-899

63. Buck JM, Como-Sabetti K, Harriman KH, Danila RN, Boxrud DJ, Glennen A, Lynfield R (2005) Community-associated methicillin-resistant Staphylococcus aureus, Minnesota, 2000 2003. Emerg Infect Dis 11(10):1532-1538

64. Daum RS, Ito T, Hiramatsu K, Hussain F, Mongkolrattanothai K, Jamklang M, Boyle-Vavra S (2002) A novel methicillinresistance cassette in community-acquired methicillin-resistant Staphylococcus aureus isolates of diverse genetic backgrounds. J Infect Dis 186(9):1344-1347

65. Lee SM, Ender M, Adhikari R, Smith JM, Berger-Bachi B, Cook GM (2007) Fitness cost of staphylococcal cassette chromosome mec in methicillin-resistant Staphylococcus aureus by way of continuous culture. Antimicrob Agents Chemother 51(4):14971499

66. Okuma K, Iwakawa K, Turnidge JD, Grubb WB, Bell JM, O'Brien FG, Coombs GW, Pearman JW, Tenover FC, Kapi M, Tiensasitorn C, Ito T, Hiramatsu K (2002) Dissemination of new methicillin-resistant Staphylococcus aureus clones in the community. J Clin Microbiol 40(11):4289-4294

67. Diep BA, Stone GG, Basuino L, Graber CJ, Miller A, des Etages SA, Jones A, Palazzolo-Ballance AM, Perdreau-Remington F, Sensabaugh GF, DeLeo FR, Chambers HF (2008) The arginine catabolic mobile element and staphylococcal chromosomal cassette mec linkage: convergence of virulence and resistance 
in the USA300 clone of methicillin-resistant Staphylococcus aureus. J Infect Dis 197(11):1523-1530

68. Collins J, Rudkin J, Recker M, Pozzi C, O'Gara JP, Massey RC (2010) Offsetting virulence and antibiotic resistance costs by MRSA. ISME J 4(4):577-584

69. Dinauer MC, Lekstrom-Himes JA, Dale DC (2000) Inherited neutrophil disorders: molecular basis and new therapies. Hematology Am Soc Hematol Educ Program, pp 303-318

70. Nauseef WM, Clark RA (2010) Chapter 8: granulocytic phagocytes. In: Mandell GL, Bennett JE, Dolin R (eds) Mandell, Douglas, and Bennett's principles and practice of infectious disease, 7th edn. Elsevier/Churchill Livingsone, New York

71. Voyich JM, Otto M, Mathema B, Braughton KR, Whitney AR, Welty D, Long RD, Dorward DW, Gardner DJ, Lina G, Kreiswirth BN, DeLeo FR (2006) Is Panton-Valentine leukocidin the major virulence determinant in community-associated methicillin-resistant Staphylococcus aureus disease? J Infect Dis 194(12):1761-1770

72. Voyich JM, Braughton KR, Sturdevant DE, Whitney AR, SaidSalim B, Porcella SF, Long RD, Dorward DW, Gardner DJ, Kreiswirth BN, Musser JM, DeLeo FR (2005) Insights into mechanisms used by Staphylococcus aureus to avoid destruction by human neutrophils. J Immunol 175(6):3907-3919

73. Bainton DF, Ullyot JL, Farquhar MG (1971) The development of neutrophilic polymorphonuclear leukocytes in human bone marrow. J Exp Med 134(4):907-934

74. Fliedner TM, Cronkite EP, Robertson JS (1964) Granulocytopoiesis. I. Senescence and random loss of neutrophilic granulocytes in human beings. Blood 24:402-414

75. Athens JW, Haab OP, Raab SO, Mauer AM, Ashenbrucker H, Cartwright GE, Wintrobe MM (1961) Leukokinetic studies. IV. The total blood, circulating and marginal granulocyte pools and the granulocyte turnover rate in normal subjects. J Clin Invest 40:989-995

76. Rossi F, Zatti M (1964) Changes in the metabolic pattern of polymorpho-nuclear leucocytes during phagocytosis. Br J Exp Pathol 45:548-559

77. Babior BM, Kipnes RS, Curnutte JT (1973) Biological defense mechanisms. The production by leukocytes of superoxide, a potential bactericidal agent. J Clin Invest 52(3):741-744

78. Klebanoff SJ (1967) Iodination of bacteria: a bactericidal mechanism. J Exp Med 126(6):1063-1078

79. Lehrer RI, Hanifin J, Cline MJ (1969) Defective bactericidal activity in myeloperoxidase-deficient human neutrophils. Nature 223(5201):78-79

80. Bainton DF, Farquhar MG (1968) Differences in enzyme content of azurophil and specific granules of polymorphonuclear leukocytes. I. Histochemical staining of bone marrow smears. J Cell Biol 39(2):286-298

81. Segal AW, Abo A (1993) The biochemical basis of the NADPH oxidase of phagocytes. Trends Biochem Sci 18(2):43-47

82. Babior BM (1999) NADPH oxidase: an update. Blood 93 (5):1464-1476

83. Clark RA (1990) The human neutrophil respiratory burst oxidase. J Infect Dis 161(6):1140-1147

84. Zigmond SH (1978) Chemotaxis by polymorphonuclear leukocytes. J Cell Biol 77(2):269-287

85. Southwick FS, Stossel TP (1983) Contractile proteins in leukocyte function. Semin Hematol 20(4):305-321

86. Borregaard N, Cowland JB (1997) Granules of the human neutrophilic polymorphonuclear leukocyte. Blood 89(10):35033521

87. Schiffmann E, Corcoran BA, Wahl SM (1975) N-formylmethionyl peptides as chemoattractants for leucocytes. Proc Natl Acad Sci USA 72(3):1059-1062
88. Snyderman R, Goetzl EJ (1981) Molecular and cellular mechanisms of leukocyte chemotaxis. Science 213(4510):830 837

89. Kaplan HB, Edelson HS, Friedman R, Weissmann G (1982) The roles of degranulation and superoxide anion generation in neutrophil aggregation. Biochim Biophys Acta 721(1):55-63

90. Smith RJ, Wierenga W, Iden SS (1980) Characteristics of Nformyl-methionyl-leucyl-phenylalanine as an inducer of lysosomal enzyme release from human neutrophils. Inflammation 4 (1):73-88

91. O'Flaherty JT (1980) Involvement of bivalent cations and arachidonic acid in neutrophil aggregation. Inflammation 4 (2):181-194

92. Korchak HM, Vienne K, Wilkenfeld C, Roberts C, Rich AM, Weissmann G (1985) The first seconds of neutrophil activation: phosphoinositides, protein kinase $\mathrm{C}$, and calcium movements. Trans Assoc Am Physicians 98:224-232

93. Andrews PC, Babior BM (1983) Endogenous protein phosphorylation by resting and activated human neutrophils. Blood 61 (2):333-340

94. Helfman DM, Appelbaum BD, Vogler WR, Kuo JF (1983) Phospholipid-sensitive $\mathrm{Ca} 2+$-dependent protein kinase and its substrates in human neutrophils. Biochem Biophys Res Commun 111(3):847-853

95. Juhl H, Nahas N, Esmann V (1982) Dephosphorylation of glycogen synthase from human polymorphonuclear leukocytes. Biochim Biophys Acta 704(3):509-514

96. Bokoch GM, Gilman AG (1984) Inhibition of receptormediated release of arachidonic acid by pertussis toxin. Cell 39(2 Pt 1):301-308

97. Lad PM, Olson CV, Smiley PA (1985) Association of the Nformyl-Met-Leu-Phe receptor in human neutrophils with a GTPbinding protein sensitive to pertussis toxin. Proc Natl Acad Sci USA 82(3):869-873

98. Korchak HM, Vosshall LB, Haines KA, Wilkenfeld C, Lundquist KF, Weissmann G (1988) Activation of the human neutrophil by calcium-mobilizing ligands. II. Correlation of calcium, diacyl glycerol, and phosphatidic acid generation with superoxide anion generation. J Biol Chem 263(23):11098-11105

99. Dillon SB, Murray JJ, Uhing RJ, Snyderman R (1987) Regulation of inositol phospholipid and inositol phosphate metabolism in chemoattractant-activated human polymorphonuclear leukocytes. J Cell Biochem 35(4):345-359

100. Verghese MW, Smith CD, Snyderman R (1985) Potential role for a guanine nucleotide regulatory protein in chemoattractant receptor mediated polyphosphoinositide metabolism, $\mathrm{Ca}++$ mobilization and cellular responses by leukocytes. Biochem Biophys Res Commun 127(2):450-457

101. Kennedy AD, DeLeo FR (2009) Neutrophil apoptosis and the resolution of infection. Immunol Res 43(1-3):25-61

102. Kobayashi SD, Braughton KR, Whitney AR, Voyich JM, Schwan TG, Musser JM, DeLeo FR (2003) Bacterial pathogens modulate an apoptosis differentiation program in human neutrophils. Proc Natl Acad Sci USA 100(19):10948-10953

103. Savill JS, Wyllie AH, Henson JE, Walport MJ, Henson PM, Haslett C (1989) Macrophage phagocytosis of aging neutrophils in inflammation. Programmed cell death in the neutrophil leads to its recognition by macrophages. J Clin Invest 83(3): $865-875$

104. Savill JS, Henson PM, Haslett C (1989) Phagocytosis of aged human neutrophils by macrophages is mediated by a novel "charge-sensitive" recognition mechanism. J Clin Invest 84 (5):1518-1527

105. Edwards SW, Moulding DA, Derouet M, Moots RJ (2003) Regulation of neutrophil apoptosis. Chem Immunol Allergy $83: 204-224$ 
106. Kobayashi SD, Voyich JM, Buhl CL, Stahl RM, DeLeo FR (2002) Global changes in gene expression by human polymorphonuclear leukocytes during receptor-mediated phagocytosis: cell fate is regulated at the level of gene expression. Proc Natl Acad Sci USA 99(10):6901-6906

107. Theilgaard-Monch K, Knudsen S, Follin P, Borregaard N (2004) The transcriptional activation program of human neutrophils in skin lesions supports their important role in wound healing. $\mathrm{J}$ Immunol 172(12):7684-7693

108. Mantovani A, Cassatella MA, Costantini C, Jaillon S (2011) Neutrophils in the activation and regulation of innate and adaptive immunity. Nat Rev Immunol 11(8):519-531

109. Tobias JD, Schleien C (1991) Granulocyte transfusions-a review for the intensive-care physician. Anaesth Intensive Care 19(4):512-520

110. Froland SS (1984) Bacterial infections in the compromised host. Scand J Infect Dis Suppl 43:7-16

111. Bodey GP, Buckley M, Sathe YS, Freireich EJ (1966) Quantitative relationships between circulating leukocytes and infection in patients with acute leukemia. Ann Intern Med 64 (2):328-340

112. Dale DC, Dt G, Wewerka JR, Bull JM, Chusid MJ (1979) Chronic neutropenia. Medicine (Baltimore) 58(2):128-144

113. Weissman IL, Anderson DJ, Gage F (2001) Stem and progenitor cells: origins, phenotypes, lineage commitments, and transdifferentiations. Annu Rev Cell Dev Biol 17:387-403

114. Rosenbauer F, Tenen DG (2007) Transcription factors in myeloid development: balancing differentiation with transformation. Nat Rev Immunol 7(2):105-117

115. Theilgaard-Monch K, Jacobsen LC, Borup R, Rasmussen T, Bjerregaard MD, Nielsen FC, Cowland JB, Borregaard N (2005) The transcriptional program of terminal granulocytic differentiation. Blood 105(4):1785-1796

116. Glasser L, Fiederlein RL (1987) Functional differentiation of normal human neutrophils. Blood 69(3):937-944

117. Cramer E, Pryzwansky KB, Villeval JL, Testa U, Breton-Gorius J (1985) Ultrastructural localization of lactoferrin and myeloperoxidase in human neutrophils by immunogold. Blood 65(2):423432

118. Csernok E, Ludemann J, Gross WL, Bainton DF (1990) Ultrastructural localization of proteinase 3 , the target antigen of anti-cytoplasmic antibodies circulating in Wegener's granulomatosis. Am J Pathol 137(5):1113-1120

119. Ohlsson K, Olsson I (1974) The neutral proteases of human granulocytes. Isolation and partial characterization of granulocyte elastases. Eur J Biochem 42(2):519-527

120. Rice WG, Ganz T, Kinkade JM Jr, Selsted ME, Lehrer RI, Parmley RT (1987) Defensin-rich dense granules of human neutrophils. Blood 70(3):757-765

121. Weiss J, Olsson I (1987) Cellular and subcellular localization of the bactericidal/permeability-increasing protein of neutrophils. Blood 69(2):652-659

122. Cieutat AM, Lobel P, August JT, Kjeldsen L, Sengelov H, Borregaard N, Bainton DF (1998) Azurophilic granules of human neutrophilic leukocytes are deficient in lysosomeassociated membrane proteins but retain the mannose 6phosphate recognition marker. Blood 91(3):1044-1058

123. Dahms NM, Lobel P, Kornfeld S (1989) Mannose 6-phosphate receptors and lysosomal enzyme targeting. J Biol Chem 264 (21):12115-12118

124. Michaelson D, Rayner J, Couto M, Ganz T (1992) Cationic defensins arise from charge-neutralized propeptides: a mechanism for avoiding leukocyte autocytotoxicity? J Leukoc Biol 51 (6):634-639

125. Nauseef WM, McCormick S, Yi H (1992) Roles of heme insertion and the mannose-6-phosphate receptor in processing of the human myeloid lysosomal enzyme, myeloperoxidase. Blood 80(10):2622-2633

126. Calafat J, Kuijpers TW, Janssen H, Borregaard N, Verhoeven AJ, Roos D (1993) Evidence for small intracellular vesicles in human blood phagocytes containing cytochrome b558 and the adhesion molecule CD11b/CD18. Blood 81(11):3122-3129

127. Borregaard N, Heiple JM, Simons ER, Clark RA (1983) Subcellular localization of the b-cytochrome component of the human neutrophil microbicidal oxidase: translocation during activation. J Cell Biol 97(1):52-61

128. Sengelov H, Boulay F, Kjeldsen L, Borregaard N (1994) Subcellular localization and translocation of the receptor for Nformylmethionyl-leucyl-phenylalanine in human neutrophils. Biochem J 299(Pt 2):473-479

129. Singer II, Scott S, Kawka DW, Kazazis DM (1989) Adhesomes: specific granules containing receptors for laminin, C3bi/fibrinogen, fibronectin, and vitronectin in human polymorphonuclear leukocytes and monocytes. J Cell Biol 109(6 Pt 1):3169-3182

130. Porteu F, Nathan CF (1992) Mobilizable intracellular pool of p55 (type I) tumor necrosis factor receptors in human neutrophils. J Leukoc Biol 52(1):122-124

131. Sengelov H, Kjeldsen L, Kroeze W, Berger M, Borregaard N (1994) Secretory vesicles are the intracellular reservoir of complement receptor 1 in human neutrophils. J Immunol 153 (2):804-810

132. Borregaard N, Kjeldsen L, Sengelov H, Diamond MS, Springer TA, Anderson HC, Kishimoto TK, Bainton DF (1994) Changes in subcellular localization and surface expression of L-selectin, alkaline phosphatase, and Mac-1 in human neutrophils during stimulation with inflammatory mediators. J Leukoc Biol 56 (1):80-87

133. Sengelov H, Kjeldsen L, Diamond MS, Springer TA, Borregaard N (1993) Subcellular localization and dynamics of Mac-1 (alpha $\mathrm{m}$ beta 2) in human neutrophils. J Clin Invest 92(3):1467-1476

134. Masson PL, Heremans JF, Schonne E (1969) Lactoferrin, an iron-binding protein in neutrophilic leukocytes. J Exp Med 130 (3):643-658

135. Lazarus GS, Brown RS, Daniels JR, Fullmer HM (1968) Human granulocyte collagenase. Science 159(3822):1483-1485

136. Murphy G, Reynolds JJ, Bretz U, Baggiolini M (1977) Collagenase is a component of the specific granules of human neutrophil leucocytes. Biochem J 162(1):195-197

137. Cline MJ (1975) Production, destruction, and distribution of neutrophilic granulocytes. The White Cell. Harvard University Press, Cambridge

138. Cronkite EP, Fliedner TM (1964) Granulocytopoiesis. N Engl J Med 270:1347-1352, CONTD

139. Hirai H, Zhang P, Dayaram T, Hetherington CJ, Mizuno S, Imanishi J, Akashi K, Tenen DG (2006) C/EBPbeta is required for 'emergency' granulopoiesis. Nat Immunol 7(7):732-739

140. Panopoulos AD, Watowich SS (2008) Granulocyte colonystimulating factor: molecular mechanisms of action during steady state and 'emergency' hematopoiesis. Cytokine 42 (3):277-288

141. Lawrence MB, Springer TA (1991) Leukocytes roll on a selectin at physiologic flow rates: distinction from and prerequisite for adhesion through integrins. Cell 65(5):859-873

142. Richter Y, Groothuis A, Seifert P, Edelman ER (2004) Dynamic flow alterations dictate leukocyte adhesion and response to endovascular interventions. J Clin Invest 113(11):1607-1614

143. Ley K, Zarbock A (2009) Neutrophil adhesion and activation under flow. Microcirculation 16(1):31-42

144. Standiford TJ, Arenberg DA, Danforth JM, Kunkel SL, VanOtteren GM, Strieter RM (1994) Lipoteichoic acid induces secretion of interleukin-8 from human blood monocytes: a cellular and molecular analysis. Infect Immun 62(1):119-125 
145. Soell M, Diab M, Haan-Archipoff G, Beretz A, Herbelin C, Poutrel B, Klein JP (1995) Capsular polysaccharide types 5 and 8 of Staphylococcus aureus bind specifically to human epithelial (KB) cells, endothelial cells, and monocytes and induce release of cytokines. Infect Immun 63(4):1380-1386

146. Yao L, Lowy FD, Berman JW (1996) Interleukin-8 gene expression in Staphylococcus aureus-infected endothelial cells. Infect Immun 64(8):3407-3409

147. Krakauer T (1998) Interleukin-8 production by human monocytic cells in response to staphylococcal exotoxins is direct and independent of interleukin-1 and tumor necrosis factor-alpha. J Infect Dis 178(2):573-577

148. McLoughlin RM, Solinga RM, Rich J, Zaleski KJ, Cocchiaro JL, Risley A, Tzianabos AO, Lee JC (2006) CD4+ T cells and CXC chemokines modulate the pathogenesis of Staphylococcus aureus wound infections. Proc Natl Acad Sci USA 103(27):10408-10413

149. Tzianabos AO, Wang JY, Lee JC (2001) Structural rationale for the modulation of abscess formation by Staphylococcus aureus capsular polysaccharides. Proc Natl Acad Sci USA 98(16):93659370

150. Schmeling DJ, Peterson PK, Hammerschmidt DE, Kim Y, Verhoef J, Wilkinson BJ, Quie PG (1979) Chemotaxigenesis by cell surface components of Staphylococcus aureus. Infect Immun 26(1):57-63

151. Showell HJ, Freer RJ, Zigmond SH, Schiffmann E, Aswanikumar S, Corcoran B, Becker EL (1976) The structure-activity relations of synthetic peptides as chemotactic factors and inducers of lysosomal secretion for neutrophils. J Exp Med 143(5):1154-1169

152. Wang R, Braughton KR, Kretschmer D, Bach TH, Queck SY, Li M, Kennedy AD, Dorward DW, Klebanoff SJ, Peschel A, DeLeo FR, Otto M (2007) Identification of novel cytolytic peptides as key virulence determinants for community-associated MRSA. Nat Med 13(12):1510-1514

153. McPhail LC, Clayton CC, Snyderman R (1984) The NADPH oxidase of human polymorphonuclear leukocytes. Evidence for regulation by multiple signals. J Biol Chem 259(9):5768-5775

154. Kobayashi SD, Voyich JM, Burlak C, DeLeo FR (2005) Neutrophils in the innate immune response. Arch Immunol Ther Exp (Warsz) 53(6):505-517

155. DeLeo FR, Renee J, McCormick S, Nakamura M, Apicella M, Weiss JP, Nauseef WM (1998) Neutrophils exposed to bacterial lipopolysaccharide upregulate NADPH oxidase assembly. J Clin Invest 101(2):455-463

156. Tedder TF, Penta AC, Levine HB, Freedman AS (1990) Expression of the human leukocyte adhesion molecule, LAM1. Identity with the TQ1 and Leu-8 differentiation antigens. J Immunol 144(2):532-540

157. Moore KL, Patel KD, Bruehl RE, Li F, Johnson DA, Lichenstein HS, Cummings RD, Bainton DF, McEver RP (1995) P-selectin glycoprotein ligand-1 mediates rolling of human neutrophils on P-selectin. J Cell Biol 128(4):661-671

158. Ley K (2002) Integration of inflammatory signals by rolling neutrophils. Immunol Rev 186:8-18

159. von Andrian UH, Chambers JD, McEvoy LM, Bargatze RF, Arfors KE, Butcher EC (1991) Two-step model of leukocyteendothelial cell interaction in inflammation: distinct roles for LECAM-1 and the leukocyte beta 2 integrins in vivo. Proc Natl Acad Sci USA 88(17):7538-7542

160. Ley K, Laudanna C, Cybulsky MI, Nourshargh S (2007) Getting to the site of inflammation: the leukocyte adhesion cascade updated. Nat Rev Immunol 7(9):678-689

161. Muller WA, Weigl SA, Deng X, Phillips DM (1993) PECAM-1 is required for transendothelial migration of leukocytes. J Exp Med 178(2):449-460

162. Diamond MS, Staunton DE, de Fougerolles AR, Stacker SA, Garcia-Aguilar J, Hibbs ML, Springer TA (1990) ICAM-1
(CD54): a counter-receptor for Mac-1 (CD11b/CD18). J Cell Biol 111(6 Pt 2):3129-3139

163. Khan AI, Kerfoot SM, Heit B, Liu L, Andonegui G, Ruffell B, Johnson P, Kubes P (2004) Role of CD44 and hyaluronan in neutrophil recruitment. J Immunol 173(12):7594-7601

164. Cooper D, Lindberg FP, Gamble JR, Brown EJ, Vadas MA (1995) Transendothelial migration of neutrophils involves integrin-associated protein (CD47). Proc Natl Acad Sci USA 92(9):3978-3982

165. Takeuchi O, Hoshino K, Akira S (2000) Cutting edge: TLR2deficient and MyD88-deficient mice are highly susceptible to Staphylococcus aureus infection. J Immunol 165(10):5392-5396

166. Kanneganti TD, Lamkanfi M, Nunez G (2007) Intracellular NOD-like receptors in host defense and disease. Immunity 27 (4):549-559

167. van de Wetering JK, van Golde LM, Batenburg JJ (2004) Collectins: players of the innate immune system. Eur J Biochem 271(7):1229-1249

168. Fujita T, Matsushita M, Endo Y (2004) The lectin-complement pathway-its role in innate immunity and evolution. Immunol Rev 198:185-202

169. Hansen S, Holm D, Moeller V, Vitved L, Bendixen C, Reid KB, Skjoedt K, Holmskov U (2002) CL-46, a novel collectin highly expressed in bovine thymus and liver. J Immunol 169(10):5726-5734

170. Liu C, Xu Z, Gupta D, Dziarski R (2001) Peptidoglycan recognition proteins: a novel family of four human innate immunity pattern recognition molecules. J Biol Chem 276 (37):34686-34694

171. Dziarski R, Platt KA, Gelius E, Steiner H, Gupta D (2003) Defect in neutrophil killing and increased susceptibility to infection with nonpathogenic gram-positive bacteria in peptidoglycan recognition protein-S (PGRP-S)-deficient mice. Blood 102(2):689-697

172. Liu C, Gelius E, Liu G, Steiner H, Dziarski R (2000) Mammalian peptidoglycan recognition protein binds peptidoglycan with high affinity, is expressed in neutrophils, and inhibits bacterial growth. J Biol Chem 275(32):24490-24499

173. Underhill DM, Gantner B (2004) Integration of Toll-like receptor and phagocytic signaling for tailored immunity. Microbe Infect 6 (15):1368-1373

174. Kennedy AD, Willment JA, Dorward DW, Williams DL, Brown GD, DeLeo FR (2007) Dectin-1 promotes fungicidal activity of human neutrophils. Eur J Immunol 37(2):467-478

175. Brouwer N, Dolman KM, van Houdt M, Sta M, Roos D, Kuijpers TW (2008) Mannose-binding lectin (MBL) facilitates opsonophagocytosis of yeasts but not of bacteria despite MBL binding. J Immunol 180(6):4124-4132

176. Fleit HB, Wright SD, Unkeless JC (1982) Human neutrophil Fc gamma receptor distribution and structure. Proc Natl Acad Sci USA 79(10):3275-3279

177. Mantovani B (1975) Different roles of $\operatorname{IgG}$ and complement receptors in phagocytosis by polymorphonuclear leukocytes. J Immunol 115(1):15-17

178. Gounni AS, Lamkhioued B, Koussih L, Ra C, Renzi PM, Hamid Q (2001) Human neutrophils express the high-affinity receptor for immunoglobulin E (Fc epsilon RI): role in asthma. FASEB J 15(6):940-949

179. Mansfield PJ, Hinkovska-Galcheva V, Carey SS, Shayman JA, Boxer LA (2002) Regulation of polymorphonuclear leukocyte degranulation and oxidant production by ceramide through inhibition of phospholipase D. Blood 99(4):1434-1441

180. Albrechtsen M, Yeaman GR, Kerr MA (1988) Characterization of the $\operatorname{IgA}$ receptor from human polymorphonuclear leucocytes. Immunology 64(2):201-205

181. Eggleton P, Ghebrehiwet B, Sastry KN, Coburn JP, Zaner KS, Reid KB, Tauber AI (1995) Identification of a gC1q-binding 
protein $(\mathrm{gClq}-\mathrm{R})$ on the surface of human neutrophils. Subcellular localization and binding properties in comparison with the cC1q-R. J Clin Invest 95(4):1569-1578

182. Rabellino EM, Ross GD, Polley MJ (1978) Membrane receptors of mouse leukocytes. I. Two types of complement receptors for different regions of C3. J Immunol 120(3):879-885

183. Ross GD, Jarowski CI, Rabellino EM, Winchester RJ (1978) The sequential appearance of Ia-like antigens and two different complement receptors during the maturation of human neutrophils. J Exp Med 147(3):730-744

184. Hickstein DD, Ozols J, Williams SA, Baenziger JU, Locksley RM, Roth GJ (1987) Isolation and characterization of the receptor on human neutrophils that mediates cellular adherence. J Biol Chem 262(12):5576-5580

185. Dana N, Todd RF 3rd, Pitt J, Springer TA, Arnaout MA (1984) Deficiency of a surface membrane glycoprotein (Mo1) in man. J Clin Invest 73(1):153-159

186. Myones BL, Dalzell JG, Hogg N, Ross GD (1988) Neutrophil and monocyte cell surface p150,95 has iC3b-receptor (CR4) activity resembling CR3. J Clin Invest 82(2):640-651

187. Lee WL, Harrison RE, Grinstein S (2003) Phagocytosis by neutrophils. Microbes Infect 5(14):1299-1306

188. Hallett MB, Dewitt S (2007) Ironing out the wrinkles of neutrophil phagocytosis. Trends Cell Biol 17(5):209-214

189. Borjesson DL, Kobayashi SD, Whitney AR, Voyich JM, Argue CM, Deleo FR (2005) Insights into pathogen immune evasion mechanisms: anaplasma phagocytophilum fails to induce an apoptosis differentiation program in human neutrophils. J Immunol 174(10):6364-6372

190. Kobayashi SD, Voyich JM, Braughton KR, DeLeo FR (2003) Down-regulation of proinflammatory capacity during apoptosis in human polymorphonuclear leukocytes. J Immunol 170 (6):3357-3368

191. Scapini P, Lapinet-Vera JA, Gasperini S, Calzetti F, Bazzoni F, Cassatella MA (2000) The neutrophil as a cellular source of chemokines. Immunol Rev 177:195-203

192. Quinn MT, Ammons MC, Deleo FR (2006) The expanding role of NADPH oxidases in health and disease: no longer just agents of death and destruction. Clin Sci (Lond) 111(1):1-20

193. Clark RA, Volpp BD, Leidal KG, Nauseef WM (1990) Two cytosolic components of the human neutrophil respiratory burst oxidase translocate to the plasma membrane during cell activation. J Clin Invest 85(3):714-721

194. DeLeo FR, Allen LA, Apicella M, Nauseef WM (1999) NADPH oxidase activation and assembly during phagocytosis. J Immunol 163(12):6732-6740

195. Heyworth PG, Bohl BP, Bokoch GM, Curnutte JT (1994) Rac translocates independently of the neutrophil NADPH oxidase components p47phox and p67phox. Evidence for its interaction with flavocytochrome b558. J Biol Chem 269(49):30749-30752

196. Volpp BD, Nauseef WM, Clark RA (1988) Two cytosolic neutrophil oxidase components absent in autosomal chronic granulomatous disease. Science 242(4883):1295-1297

197. Klebanoff SJ (1968) Myeloperoxidase-halide-hydrogen peroxide antibacterial system. J Bacteriol 95(6):2131-2138

198. Rosen H, Klebanoff SJ (1977) Formation of singlet oxygen by the myeloperoxidase-mediated antimicrobial system. J Biol Chem 252(14):4803-4810

199. Marcinkiewicz J (1997) Neutrophil chloramines: missing links between innate and acquired immunity. Immunol Today 18 (12):577-580

200. Klebanoff SJ (2005) Myeloperoxidase: friend and foe. J Leukoc Biol 77(5):598-625

201. Rada BK, Geiszt M, Hably C, Ligeti E (2005) Consequences of the electrogenic function of the phagocytic NADPH oxidase. Philos Trans R Soc Lond B Biol Sci 360(1464):2293-2300
202. DeCoursey TE, Cherny VV, Zhou W, Thomas LL (2000) Simultaneous activation of NADPH oxidase-related proton and electron currents in human neutrophils. Proc Natl Acad Sci USA 97(12):6885-6889

203. Lomax KJ, Leto TL, Nunoi H, Gallin JI, Malech HL (1989) Recombinant 47-kilodalton cytosol factor restores NADPH oxidase in chronic granulomatous disease. Science 245 (4916):409-412

204. Matute JD, Arias AA, Dinauer MC, Patino PJ (2005) p40phox: the last NADPH oxidase subunit. Blood Cells Mol Dis 35 (2):291-302

205. Bissonnette SA, Glazier CM, Stewart MQ, Brown GE, Ellson CD, Yaffe MB (2008) Phosphatidylinositol 3-phosphatedependent and -independent functions of p40phox in activation of the neutrophil NADPH oxidase. J Biol Chem 283(4):21082119

206. Tian W, Li XJ, Stull ND, Ming W, Suh CI, Bissonnette SA, Yaffe MB, Grinstein S, Atkinson SJ, Dinauer MC (2008) Fc gamma R-stimulated activation of the NADPH oxidase: phosphoinositide-binding protein p40phox regulates NADPH oxidase activity after enzyme assembly on the phagosome. Blood 112(9):3867-3877

207. McPhail LC (1994) SH3-dependent assembly of the phagocyte NADPH oxidase. J Exp Med 180(6):2011-2015

208. Leto TL, Adams AG, de Mendez I (1994) Assembly of the phagocyte NADPH oxidase: binding of Src homology 3 domains to proline-rich targets. Proc Natl Acad Sci USA 91(22):10650 10654

209. Lekstrom-Himes JA, Gallin JI (2000) Immunodeficiency diseases caused by defects in phagocytes. N Engl J Med 343 (23): $1703-1714$

210. Nauseef WM (1990) Myeloperoxidase deficiency. Hematol Pathol 4(4):165-178

211. Rosen H, Klebanoff SJ (1979) Bactericidal activity of a superoxide anion-generating system. A model for the polymorphonuclear leukocyte. J Exp Med 149(1):27-39

212. Odell EW, Segal AW (1988) The bactericidal effects of the respiratory burst and the myeloperoxidase system isolated in neutrophil cytoplasts. Biochim Biophys Acta 971(3):266-274

213. Klebanoff SJ (1970) Myeloperoxidase: contribution to the microbicidal activity of intact leukocytes. Science 169 (950):1095-1097

214. Nauseef WM (2007) How human neutrophils kill and degrade microbes: an integrated view. Immunol Rev 219:88-102

215. Faurschou M, Borregaard N (2003) Neutrophil granules and secretory vesicles in inflammation. Microbes Infect 5(14):13171327

216. Hirsch JG, Cohn ZA (1960) Degranulation of polymorphonuclear leucocytes following phagocytosis of microorganisms. J Exp Med 112:1005-1014

217. Oram JD, Reiter B (1968) Inhibition of bacteria by lactoferrin and other iron-chelating agents. Biochim Biophys Acta 170 (2):351-365

218. Cohen MS, Britigan BE, Hassett DJ, Rosen GM (1988) Phagocytes, $\mathrm{O} 2$ reduction, and hydroxyl radical. Rev Infect Dis 10(6):1088-1096

219. Corbin BD, Seeley EH, Raab A, Feldmann J, Miller MR, Torres VJ, Anderson KL, Dattilo BM, Dunman PM, Gerads R, Caprioli RM, Nacken W, Chazin WJ, Skaar EP (2008) Metal chelation and inhibition of bacterial growth in tissue abscesses. Science 319(5865):962-965

220. Femling JK, Nauseef WM, Weiss JP (2005) Synergy between extracellular group IIA phospholipase A2 and phagocyte NADPH oxidase in digestion of phospholipids of Staphylococcus aureus ingested by human neutrophils. J Immunol 175 (7):4653-4661 
221. Brinkmann V, Reichard U, Goosmann C, Fauler B, Uhlemann Y, Weiss DS, Weinrauch Y, Zychlinsky A (2004) Neutrophil extracellular traps kill bacteria. Science 303(5663):1532-1535

222. Papayannopoulos V, Zychlinsky A (2009) NETs: a new strategy for using old weapons. Trends Immunol 30(11):513-521

223. von Kockritz-Blickwede M, Nizet V (2009) Innate immunity turned inside-out: antimicrobial defense by phagocyte extracellular traps. J Mol Med (Berl) 87(8):775-783

224. Fuchs TA, Abed U, Goosmann C, Hurwitz R, Schulze I, Wahn V, Weinrauch Y, Brinkmann V, Zychlinsky A (2007) Novel cell death program leads to neutrophil extracellular traps. J Cell Biol 176(2):231-241

225. Cohen JJ, Duke RC, Fadok VA, Sellins KS (1992) Apoptosis and programmed cell death in immunity. Annu Rev Immunol $10: 267-293$

226. DeLeo FR (2004) Modulation of phagocyte apoptosis by bacterial pathogens. Apoptosis 9(4):399-413

227. Savill J (1997) Apoptosis in resolution of inflammation. J Leukoc Biol 61(4):375-380

228. Shi J, Gilbert GE, Kokubo Y, Ohashi T (2001) Role of the liver in regulating numbers of circulating neutrophils. Blood 98 (4): $1226-1230$

229. Coxon A, Rieu P, Barkalow FJ, Askari S, Sharpe AH, von Andrian UH, Arnaout MA, Mayadas TN (1996) A novel role for the beta 2 integrin CD11b/CD18 in neutrophil apoptosis: a homeostatic mechanism in inflammation. Immunity 5(6):653666

230. Gamberale R, Giordano M, Trevani AS, Andonegui G, Geffner JR (1998) Modulation of human neutrophil apoptosis by immune complexes. J Immunol 161(7):3666-3674

231. Colotta F, Re F, Polentarutti N, Sozzani S, Mantovani A (1992) Modulation of granulocyte survival and programmed cell death by cytokines and bacterial products. Blood 80(8):2012-2020

232. Engelich G, White M, Hartshorn KL (2001) Neutrophil survival is markedly reduced by incubation with influenza virus and Streptococcus pneumoniae: role of respiratory burst. J Leukoc Biol 69(1):50-56

233. Watson RW, Redmond HP, Wang JH, Bouchier-Hayes D (1996) Bacterial ingestion, tumor necrosis factor-alpha, and heat induce programmed cell death in activated neutrophils. Shock 5(1):47-51

234. Whyte MK, Meagher LC, MacDermot J, Haslett C (1993) Impairment of function in aging neutrophils is associated with apoptosis. J Immunol 150(11):5124-5134

235. Fadok VA, Bratton DL, Henson PM (2001) Phagocyte receptors for apoptotic cells: recognition, uptake, and consequences. J Clin Invest 108(7):957-962

236. Voll RE, Herrmann M, Roth EA, Stach C, Kalden JR, Girkontaite I (1997) Immunosuppressive effects of apoptotic cells. Nature 390(6658):350-351

237. Huynh ML, Fadok VA, Henson PM (2002) Phosphatidylserinedependent ingestion of apoptotic cells promotes TGF-betal secretion and the resolution of inflammation. J Clin Invest 109(1):41-50

238. Fadok VA, Bratton DL, Konowal A, Freed PW, Westcott JY, Henson PM (1998) Macrophages that have ingested apoptotic cells in vitro inhibit proinflammatory cytokine production through autocrine/paracrine mechanisms involving TGF-beta, PGE2, and PAF. J Clin Invest 101(4):890-898

239. Li MO, Sarkisian MR, Mehal WZ, Rakic P, Flavell RA (2003) Phosphatidylserine receptor is required for clearance of apoptotic cells. Science 302(5650):1560-1563

240. Botto M, Dell'Agnola C, Bygrave AE, Thompson EM, Cook HT, Petry F, Loos M, Pandolfi PP, Walport MJ (1998) Homozygous C1q deficiency causes glomerulonephritis associated with multiple apoptotic bodies. Nat Genet 19(1):56-59

241. O'Riordan K, Lee JC (2004) Staphylococcus aureus capsular polysaccharides. Clin Microbiol Rev 17(1):218-234
242. Mack D, Fischer W, Krokotsch A, Leopold K, Hartmann R, Egge H, Laufs R (1996) The intercellular adhesin involved in biofilm accumulation of Staphylococcus epidermidis is a linear beta-1,6-linked glucosaminoglycan: purification and structural analysis. J Bacteriol 178(1):175-183

243. Vuong C, Kocianova S, Voyich JM, Yao Y, Fischer ER, DeLeo FR, Otto M (2004) A crucial role for exopolysaccharide modification in bacterial biofilm formation, immune evasion, and virulence. J Biol Chem 279(52):54881-54886

244. Vuong C, Voyich JM, Fischer ER, Braughton KR, Whitney AR, DeLeo FR, Otto M (2004) Polysaccharide intercellular adhesin (PIA) protects Staphylococcus epidermidis against major components of the human innate immune system. Cell Microbiol 6(3):269-275

245. Forsgren A, Nordstrom K (1974) Protein A from Staphylococcus aureus: the biological significance of its reaction with IgG. Ann N Y Acad Sci 236:252-266

246. Langone JJ (1982) Protein A of Staphylococcus aureus and related immunoglobulin receptors produced by streptococci and pneumonococci. Adv Immunol 32:157-252

247. de Haas CJ, Veldkamp KE, Peschel A, Weerkamp F, Van Wamel WJ, Heezius EC, Poppelier MJ, Van Kessel KP, van Strijp JA (2004) Chemotaxis inhibitory protein of Staphylococcus aureus, a bacterial antiinflammatory agent. J Exp Med 199(5):687-695

248. Rooijakkers SH, Ruyken M, Roos A, Daha MR, Presanis JS, Sim RB, van Wamel WJ, van Kessel KP, van Strijp JA (2005) Immune evasion by a staphylococcal complement inhibitor that acts on C3 convertases. Nat Immunol 6(9):920-927

249. Liu GY, Essex A, Buchanan JT, Datta V, Hoffman HM, Bastian JF, Fierer J, Nizet V (2005) Staphylococcus aureus golden pigment impairs neutrophil killing and promotes virulence through its antioxidant activity. J Exp Med 202(2):209-215

250. Sieprawska-Lupa M, Mydel P, Krawczyk K, Wojcik K, Puklo M, Lupa B, Suder P, Silberring J, Reed M, Pohl J, Shafer W, McAleese F, Foster T, Travis J, Potempa J (2004) Degradation of human antimicrobial peptide LL-37 by Staphylococcus aureusderived proteinases. Antimicrob Agents Chemother 48(12):46734679

251. Li M, Cha DJ, Lai Y, Villaruz AE, Sturdevant DE, Otto M (2007) The antimicrobial peptide-sensing system aps of Staphylococcus aureus. Mol Microbiol 66(5):1136-1147

252. Li M, Lai Y, Villaruz AE, Cha DJ, Sturdevant DE, Otto M (2007) Gram-positive three-component antimicrobial peptidesensing system. Proc Natl Acad Sci USA 104(22):9469-9474

253. Peschel A, Jack RW, Otto M, Collins LV, Staubitz P, Nicholson G, Kalbacher H, Nieuwenhuizen WF, Jung G, Tarkowski A, van Kessel KP, van Strijp JA (2001) Staphylococcus aureus resistance to human defensins and evasion of neutrophil killing via the novel virulence factor $\mathrm{MprF}$ is based on modification of membrane lipids with 1-lysine. J Exp Med 193(9):1067-1076

254. Peschel A, Otto M, Jack RW, Kalbacher H, Jung G, Gotz F (1999) Inactivation of the dlt operon in Staphylococcus aureus confers sensitivity to defensins, protegrins, and other antimicrobial peptides. J Biol Chem 274(13):8405-8410

255. Joubert O, Voegelin J, Guillet V, Tranier S, Werner S, Colin DA, Serra MD, Keller D, Monteil H, Mourey L, Prevost G (2007) Distinction between pore assembly by staphylococcal alphatoxin versus leukotoxins. J Biomed Biotechnol 2007(1):25935

256. McCormick JK, Yarwood JM, Schlievert PM (2001) Toxic shock syndrome and bacterial superantigens: an update. Annu Rev Microbiol 55:77-104

257. Dinges MM, Orwin PM, Schlievert PM (2000) Exotoxins of Staphylococcus aureus. Clin Microbiol Rev 13(1):16-34, table of contents

258. Yoshiie K, Kim HY, Mott J, Rikihisa Y (2000) Intracellular infection by the human granulocytic ehrlichiosis agent inhibits human neutrophil apoptosis. Infect Immun 68(3):1125-1133 
259. Kobayashi SD, Braughton KR, Palazzolo-Ballance AM, Kennedy AD, Sampaio E, Kristosturyan E, Whitney AR, Sturdevant DE, Dorward DW, Holland SM, Kreiswirth BN, Musser JM, DeLeo FR (2010) Rapid neutrophil destruction following phagocytosis of Staphylococcus aureus. J Innate Immun 2(6):560-575

260. Bhakdi S, Tranum-Jensen J (1991) Alpha-toxin of Staphylococcus aureus. Microbiol Rev 55(4):733-751

261. Valeva A, Walev I, Pinkernell M, Walker B, Bayley H, Palmer M, Bhakdi S (1997) Transmembrane beta-barrel of staphylococcal alpha-toxin forms in sensitive but not in resistant cells. Proc Natl Acad Sci USA 94(21):11607-11611

262. Bubeck Wardenburg J, Bae T, Otto M, Deleo FR, Schneewind O (2007) Poring over pores: alpha-hemolysin and Panton-Valentine leukocidin in Staphylococcus aureus pneumonia. Nat Med 13 (12):1405-1406

263. Bubeck Wardenburg J, Schneewind O (2008) Vaccine protection against Staphylococcus aureus pneumonia. J Exp Med 205 (2):287-294

264. Bartlett AH, Foster TJ, Hayashida A, Park PW (2008) Alpha-toxin facilitates the generation of CXC chemokine gradients and stimulates neutrophil homing in Staphylococcus aureus pneumonia. J Infect Dis 198(10):1529-1535

265. Montgomery CP, Boyle-Vavra S, Adem PV, Lee JC, Husain AN, Clasen J, Daum RS (2008) Comparison of virulence in community-associated methicillin-resistant Staphylococcus aureus pulsotypes USA300 and USA400 in a rat model of pneumonia. J Infect Dis 198(4):561-570

266. Burlak C, Hammer CH, Robinson MA, Whitney AR, McGavin MJ, Kreiswirth BN, Deleo FR (2007) Global analysis of community-associated methicillin-resistant Staphylococcus aureus exoproteins reveals molecules produced in vitro and during infection. Cell Microbiol 9(5):1172-1190

267. Kobayashi SD, Malachowa N, Whitney AR, Braughton KR, Gardner DJ, Long D, Bubeck Wardenburg J, Schneewind O, Otto M, Deleo FR (2011) Comparative analysis of USA300 virulence determinants in a rabbit model of skin and soft tissue infection. J Infect Dis 204(6):937-941

268. Kennedy AD, Bubeck Wardenburg J, Gardner DJ, Long D, Whitney AR, Braughton KR, Schneewind O, DeLeo FR (2010) Targeting of alpha-hemolysin by active or passive immunization decreases severity of USA300 skin infection in a mouse model. J Infect Dis 202(7):1050-1058

269. Li M, Diep BA, Villaruz AE, Braughton KR, Jiang X, DeLeo FR, Chambers HF, Lu Y, Otto M (2009) Evolution of virulence in epidemic community-associated methicillin-resistant Staphylococcus aureus. Proc Natl Acad Sci USA 106(14):5883-5888

270. Diep BA, Gill SR, Chang RF, Phan TH, Chen JH, Davidson MG, Lin F, Lin J, Carleton HA, Mongodin EF, Sensabaugh GF, Perdreau-Remington F (2006) Complete genome sequence of USA300, an epidemic clone of community-acquired meticillinresistant Staphylococcus aureus. Lancet 367(9512):731-739

271. Moncada S, Higgs A (1993) The L-arginine-nitric oxide pathway. N Engl J Med 329(27):2002-2012

272. Montgomery CP, Boyle-Vavra S, Daum RS (2009) The arginine catabolic mobile element is not associated with enhanced virulence in experimental invasive disease caused by the community-associated methicillin-resistant Staphylococcus aureus USA300 genetic background. Infect Immun 77(7):2650-2656

273. Kaneko J, Kimura T, Narita S, Tomita T, Kamio Y (1998) Complete nucleotide sequence and molecular characterization of the temperate staphylococcal bacteriophage phiPVL carrying Panton-Valentine leukocidin genes. Gene 215(1):57-67

274. Meyer F, Girardot R, Piemont Y, Prevost G, Colin DA (2009) Analysis of the specificity of Panton-Valentine leucocidin and gamma-hemolysin F component binding. Infect Immun 77 (1):266-273
275. Colin DA, Mazurier I, Sire S, Finck-Barbancon V (1994) Interaction of the two components of leukocidin from Staphylococcus aureus with human polymorphonuclear leukocyte membranes: sequential binding and subsequent activation. Infect Immun 62(8):3184-3188

276. Konig B, Prevost G, Piemont Y, Konig W (1995) Effects of Staphylococcus aureus leukocidins on inflammatory mediator release from human granulocytes. J Infect Dis 171(3):607-613

277. Woodin AM, Wieneke AA (1964) The participation of calcium, adenosine triphosphate and adenosine triphosphatase in the extrusion of the granule proteins from the polymorphonuclear leucocyte. Biochem J 90(3):498-509

278. Genestier AL, Michallet MC, Prevost G, Bellot G, Chalabreysse L, Peyrol S, Thivolet F, Etienne J, Lina G, Vallette FM, Vandenesch F, Genestier L (2005) Staphylococcus aureus Panton-Valentine leukocidin directly targets mitochondria and induces Bax-independent apoptosis of human neutrophils. J Clin Invest 115(11):3117-3127

279. Colin DA, Monteil H (2003) Control of the oxidative burst of human neutrophils by staphylococcal leukotoxins. Infect Immun 71(7):3724-3729

280. Lina G, Piemont Y, Godail-Gamot F, Bes M, Peter MO, Gauduchon V, Vandenesch F, Etienne J (1999) Involvement of PantonValentine leukocidin-producing Staphylococcus aureus in primary skin infections and pneumonia. Clin Infect Dis 29(5):1128-1132

281. Gillet Y, Issartel B, Vanhems P, Fournet JC, Lina G, Bes M, Vandenesch F, Piemont Y, Brousse N, Floret D, Etienne J (2002) Association between Staphylococcus aureus strains carrying gene for Panton-Valentine leukocidin and highly lethal necrotising pneumonia in young immunocompetent patients. Lancet 359 (9308):753-759

282. Gillet Y, Vanhems P, Lina G, Bes M, Vandenesch F, Floret D, Etienne J (2007) Factors predicting mortality in necrotizing communityacquired pneumonia caused by Staphylococcus aureus containing Panton-Valentine leukocidin. Clin Infect Dis 45(3):315-321

283. Roundtree PaF V (1956) Infections caused by a particular phage type of Staphylococcus aureus. Med J Aust 42:157-161

284. Tseng CW, Kyme P, Low J, Rocha MA, Alsabeh R, Miller LG, Otto M, Arditi M, Diep BA, Nizet V, Doherty TM, Beenhouwer DO, Liu GY (2009) Staphylococcus aureus Panton-Valentine leukocidin contributes to inflammation and muscle tissue injury. PLoS One 4(7):e6387

285. Diep BA, Palazzolo-Ballance AM, Tattevin P, Basuino L, Braughton KR, Whitney AR, Chen L, Kreiswirth BN, Otto M, DeLeo FR, Chambers HF (2008) Contribution of Panton-Valentine leukocidin in community-associated methicillin-resistant Staphylococcus aureus pathogenesis. PLoS One 3(9):e3198

286. Montgomery CP, Daum RS (2009) Transcription of inflammatory genes in the lung after infection with community-associated methicillin-resistant Staphylococcus aureus: a role for PantonValentine leukocidin? Infect Immun 77(5):2159-2167

287. Bubeck Wardenburg J, Palazzolo-Ballance AM, Otto M, Schneewind O, DeLeo FR (2008) Panton-Valentine leukocidin is not a virulence determinant in murine models of community-associated methicillinresistant Staphylococcus aureus disease. J Infect Dis 198(8):11661170

288. Brown EL, Dumitrescu O, Thomas D, Badiou C, Koers EM, Choudhury P, Vazquez V, Etienne J, Lina G, Vandenesch F, Bowden MG (2009) The Panton-Valentine leukocidin vaccine protects mice against lung and skin infections caused by Staphylococcus aureus USA300. Clin Microbiol Infect 15(2): $156-164$

289. Graves SF, Kobayashi SD, Braughton KR, Diep BA, Chambers HF, Otto M, Deleo FR (2010) Relative contribution of PantonValentine leukocidin to PMN plasma membrane permeability and lysis caused by USA300 and USA400 culture supernatants. Microbe Infect 12(6):446-456 
290. Szmigielski S, Prevost G, Monteil H, Colin DA, Jeljaszewicz J (1999) Leukocidal toxins of staphylococci. Zentralbl Bakteriol 289(2):185-201

291. Lipinska U, Hermans K, Meulemans L, Dumitrescu O, Badiou C, Duchateau L, Haesebrouck F, Etienne J, Lina G (2011) Panton-Valentine leukocidin does play a role in the early stage of staphylococcus aureus skin infections: a rabbit model. PLoS One 6(8):e22864

292. Ventura CL, Malachowa N, Hammer CH, Nardone GA, Robinson MA, Kobayashi SD, DeLeo FR (2010) Identification of a novel Staphylococcus aureus two-component leukotoxin using cell surface proteomics. PLoS One 5(7):e11634

293. Bonilla FA, Geha RS (2003) 12. Primary immunodeficiency diseases. J Allergy Clin Immunol 111(2 Suppl):S571-S581
294. Lim MS, Elenitoba-Johnson KS (2004) The molecular pathology of primary immunodeficiencies. J Mol Diagn 6(2):59-83

295. Kumar A, Teuber SS, Gershwin ME (2006) Current perspectives on primary immunodeficiency diseases. Clin Dev Immunol 13 (2-4):223-259

296. Bernini JC (1996) Diagnosis and management of chronic neutropenia during childhood. Pediatr Clin North Am 43 (3):773-792

297. Schaffer AC, Lee JC (2009) Staphylococcal vaccines and immunotherapies. Infect Dis Clin North Am 23(1):153-171

298. DeLeo FR, Otto M (2008) An antidote for Staphylococcus aureus pneumonia? J Exp Med 205(2):271-274

299. Otto M (2008) Targeted immunotherapy for staphylococcal infections: focus on anti-MSCRAMM antibodies. Bio Drugs 22(1):27-36 